\title{
Fate of potassium fertilisers applied to clay soils under rainfed grain cropping in south-east Queensland, Australia
}

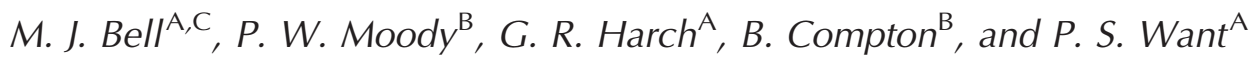 \\ ${ }^{A}$ Queensland Department of Primary Industries and Fisheries, PO Box 23, Kingaroy, Qld 4610, Australia. \\ ${ }^{B}$ Queensland Department of Natural Resources and Water, Indooroopilly, Qld 4068, Australia. \\ ${ }^{\mathrm{C} C o r r e s p o n d i n g ~ a u t h o r . ~ E m a i l: ~ m i k e . b e l l @ d p i . q l d . g o v . a u ~}$
}

\begin{abstract}
Negative potassium (K) balances in all broadacre grain cropping systems in northern Australia are resulting in a decline in the plant-available reserves of $\mathrm{K}$ and necessitating a closer examination of strategies to detect and respond to developing K deficiency in clay soils. Grain growers on the Red Ferrosol soils have increasingly encountered K deficiency over the last 10 years due to lower available K reserves in these soils in their native condition. However, the problem is now increasingly evident on the medium-heavy clay soils (Black and Grey Vertosols) and is made more complicated by the widespread adoption of direct drill cropping systems and the resulting strong stratification of available K reserves in the top $0.05-0.1 \mathrm{~m}$ of the soil profile. This paper reports glasshouse studies examining the fate of applied K fertiliser in key cropping soils of the inland Burnett region of south-east Queensland, and uses the resultant understanding of K dynamics to interpret results of field trials assessing the effectiveness of $\mathrm{K}$ application strategies in terms of $\mathrm{K}$ availability to crop plants.

At similar concentrations of exchangeable $\mathrm{K}\left(\mathrm{K}_{\mathrm{exch}}\right)$, soil solution $\mathrm{K}$ concentrations and activity of $\mathrm{K}$ in the soil solution $\left(A R_{K}\right)$ varied by 6-7-fold between soil types. When $K_{\text {exch }}$ arising from different rates of fertiliser application was expressed as a percentage of the effective cation exchange capacity (i.e. $\mathrm{K}$ saturation), there was evidence of greater selective adsorption of $\mathrm{K}$ on the exchange complex of Red Ferrosols than Black and Grey Vertosols or Brown Dermosols. Both soil solution $\mathrm{K}$ and $\mathrm{AR}_{\mathrm{K}}$ were much less responsive to increasing $\mathrm{K}_{\text {exch }}$ in the Black Vertosols; this is indicative of these soils having a high $\mathrm{K}$ buffer capacity (KBC). These contrasting properties have implications for the rate of diffusive supply of $\mathrm{K}$ to plant roots and the likely impact of $\mathrm{K}$ application strategies (banding $v$. broadcast and incorporation) on plant $\mathrm{K}$ uptake.

Field studies investigating $\mathrm{K}$ application strategies (banding $v$. broadcasting) and the interaction with the degree of soil disturbance/mixing of different soil types are discussed in relation to K dynamics derived from glasshouse studies. Greater propensity to accumulate luxury $\mathrm{K}$ in crop biomass was observed in a Brown Ferrosol with a KBC lower than that of a Black Vertosol, consistent with more efficient diffusive supply to plant roots in the Ferrosol. This luxury K uptake, when combined with crops exhibiting low proportional removal of $\mathrm{K}$ in the harvested product (i.e. low $\mathrm{K}$ harvest index coarse grains and winter cereals) and residue retention, can lead to rapid re-development of stratified K profiles.

There was clear evidence that some incorporation of $\mathrm{K}$ fertiliser into soil was required to facilitate root access and crop uptake, although there was no evidence of a need to incorporate $\mathrm{K}$ fertiliser any deeper than achieved by conventional disc tillage (i.e. $0.1-0.15 \mathrm{~m})$. Recovery of fertiliser $\mathrm{K}$ applied in deep $(0.25-0.3 \mathrm{~m})$ bands in combination with $\mathrm{N}$ and $\mathrm{P}$ to facilitate root proliferation was quite poor in Red Ferrosols and Grey or Black Vertosols with moderate effective cation exchange capacity $(\mathrm{ECEC}, 25-35 \mathrm{cmol}(+) / \mathrm{kg}$ ), was reasonable but not enough to overcome $\mathrm{K}$ deficiency in a Brown Dermosol (ECEC $11 \mathrm{cmol}(+) / \mathrm{kg})$, but was quite good on a Black Vertosol (ECEC 50-60 $\mathrm{cmol}(+) / \mathrm{kg}$ ).

Collectively, results suggest that frequent small applications of $\mathrm{K}$ fertiliser, preferably with some soil mixing, is an effective fertiliser application strategy on lighter clay soils with low KBC and an effective diffusive supply mechanism. Alternately, concentrated $\mathrm{K}$ bands and enhanced root proliferation around them may be a more effective strategy in Vertosol soils with high KBC and limited diffusive supply. Further studies to assess this hypothesis are needed.
\end{abstract}

\section{Introduction}

Potassium $(\mathrm{K})$ is a nutrient required in large quantities by crop plants, with only nitrogen found in greater concentrations in plant biomass (Syers 1998). However, K fertiliser inputs in Australian cropping systems have generally been low relative to other high-yielding production systems (Pretty and Stangel 1985). Reuter et al. (1997) estimated that nationally Australia had a negative $\mathrm{K}$ balance, and in broadacre cropping regions this balance was strongly negative. This estimate was confirmed by the 'farm gate nutrient balances' (nutrient input in fertilisers, rainfall, and irrigation water minus nutrient removed off-site in harvested product) calculated for the intensive land-use zone of Australia by the Australian National Land and Water Resources Audit. This study concluded that a negative $\mathrm{K}$ budget existed across many areas and cropping systems (Australian Agriculture Assessment 2001), and consistent with this general observation there has been increasing evidence of K deficiency in soils of the Western Australian wheat belt (Wong et al. 2001). 
In Queensland, negative K balances were almost universal, with the exception of some areas of intensive horticulture in coastal areas (Australian Agriculture Assessment 2001). Even the sugar industry, which has a history of significant $\mathrm{K}$ fertiliser inputs, shows negative $\mathrm{K}$ balances and a decline in soil $\mathrm{K}$ reserves (Wood and Schroeder 2004). The major broadacre grain cropping areas of inland Queensland, where cereal grains, cotton, and grain legumes are grown on soils with moderate to high clay contents and, in pre-cropping condition, moderate to high levels of chemical soil fertility (Webb et al. 1997), are also characterised by negative $\mathrm{K}$ balances. The negative $\mathrm{K}$ balances recorded for rainfed cropping systems in the Red Ferrosol (Isbell 1996) soils of the inland Burnett (Bell and Moody 2001) are consistent with the widespread evidence of declining and increasingly stratified soil $\mathrm{K}$ reserves, leading to $\mathrm{K}$ deficiency and yield losses (Bell et al. 1995). There is also an increasing frequency of reports of $\mathrm{K}$ deficiency on other soil types in the northern region (e.g. some Vertosols, Bedrossian and Singh 2004; Bell et al. 2005) that is consistent with declining soil $\mathrm{K}$ reserves, although the most common reports are so far associated with highyielding cotton crops (Wright 1999). The situation on many of these soils is complicated by the presence of fixed and/or structural K pools not accounted for by current commercial soil tests that measure exchangeable K (Moody and Bell 2006).

Once $\mathrm{K}$ deficiency is recognised as a constraint to productivity, or as soils are diagnosed as being in the later stages of declining $\mathrm{K}$ reserves, the key issues then become determining when to start applying soil $\mathrm{K}$ amendments and how to apply those amendments most effectively (both in economic and production terms). Soil test methodologies to determine the size of some of the $\mathrm{K}$ pools (e.g. solution $\mathrm{K}$ and exchangeable $\mathrm{K}$ ) are well established, but there is still conjecture over methodologies to quantify 'fixed' $\mathrm{K}$ and 'structural' $\mathrm{K}$, in addition to predicting the availability of these more recalcitrant pools for plant uptake (Moody and Bell 2006).

Even if the plant-available $\mathrm{K}$ status of clay soils could be reliably predicted, the most effective $\mathrm{K}$ fertiliser application strategies have yet to be determined and the economics of reliability of grain yield responses (cf. biomass) in rainfed production systems are uncertain. In crop and pasture systems in south-west Western Australia, where sandy soils predominate and redistribution of applied $\mathrm{K}$ down the profile by leaching is often recorded (Barrow 1967; Edwards 1998), surface broadcasting of $\mathrm{K}$ fertilisers after crop or pasture establishment is an effective way of amending K-deficient soils. However, this approach is not suitable for heavier textured soils typical of rain-fed cropping systems in Queensland and northern New South Wales, as leaching of K does not readily occur in clay loam soils with moderate cation exchange capacities, such as the Red Ferrosols of the inland Burnett (White 2002). The strongly stratified $\mathrm{K}$ profiles observed in many of the Vertosols of the grain-cropping region of northeastern Australia, even at uncropped reference sites (McKenzie et al. 2004; M. J. Bell, D. Lawrence, and K. E. Klepper, unpublished data), also suggest limited leaching of $\mathrm{K}$. In cropping systems on these soils, the lack of potential redistribution by leaching is exacerbated by reduced profile mixing from mechanical tillage in reduced and zero tillage systems, and drier seasonal conditions are ensuring that topsoil nutrient reserves are often unavailable for root uptake. Arecent example of this was provided by Wangetal. (2007), who showed that even when long-term applications of $\mathrm{P}$ fertiliser in excess of crop requirements were made to the top $0.1 \mathrm{~m}$ layer of a Vertosol under rainfed cropping, significant rundown in soil $\mathrm{P}$ reserves (up to $50 \%$ of total $\mathrm{P}$ removal from unfertilised plots) occurred in the $0.1-0.6 \mathrm{~m}$ depths of the soil profile. It is expected that similar processes of subsoil depletion and surface enrichment of available $\mathrm{K}$ reserves would be contributing to the observed stratification of this nutrient.

Fertilisers are primarily applied by banding in these rainfed cropping systems, either before sowing $(\mathrm{N})$, in the seeding row at planting $(\mathrm{N}, \mathrm{P}$, and trace elements such as $\mathrm{Zn})$, or as a sidedressing after crop establishment $(\mathrm{N})$. However, there are limited opportunities to add $\mathrm{K}$ fertilisers to the mix applied at planting, especially in crops grown in rows spaced $0.75-1.5 \mathrm{~m}$ apart, due to negative impacts on crop establishment through salt effects. White (2002) conducted several experiments to examine responses to muriate of potash $(\mathrm{KCl})$ applications in deep bands (c. $0.3 \mathrm{~m}$ deep) by rainfed crops on Red Ferrosols. These studies indicated poor recovery of applied K from deep bands, despite several crops clearly showing $\mathrm{K}$ deficiency symptoms, and it was hypothesised that the lack of response was due to either the small soil volume enriched by banded $\mathrm{K}$ applications or an inability of crops to proliferate roots in and around the $\mathrm{KCl}$ band.

In addition to these uncertainties with application strategy, there are also suggestions that once $\mathrm{K}$ deficiencies are encountered in some of the heavier clay soils with high cation exchange capacity (CEC; e.g. those used for intensive lucerne production; Collett 1997), broadcast $\mathrm{K}$ application rates of the order of $500 \mathrm{~kg} \mathrm{~K} / \mathrm{ha}$ are necessary to overcome the growth limitation. Whether these high rates are due to factors associated with cation competition in the soil solution in situations of high cation buffering capacity (high CEC and base saturation), or due to competition between plants and sites of $\mathrm{K}$ fixation in the clay matrix, has yet to be determined.

This paper reports results from laboratory assays and longterm field experiments with varying $\mathrm{K}$ fertiliser application strategies (rates, forms, and placement) on soils with differing clay contents and mineralogies used for broadacre grain, grain legume, and cotton production. Trials were designed to (i) investigate responses to applied $\mathrm{K}$ fertilisers on key cropping soils of the inland Burnett region of north-east Australia; (ii) determine whether $\mathrm{K}$ recovery could be improved by addition of $\mathrm{N}$ and $\mathrm{P}$ to the fertiliser band; and (iii) determine responses to different profile distributions of $\mathrm{K}$ achieved by differing levels of tillage and profile inversion.

\section{Materials and methods}

The research was conducted at field sites, and on soil collected from the cultivated layer (top $0.1 \mathrm{~m}$ of the profile) of those field sites, located on the main cropping soils of the inland Burnett region of south-east Queensland, Australia (Table 1). Soil types (Isbell 1996) ranged from heavy-textured Black and Grey Vertosols (65-75\% clay), through to lighter textured Brown Dermosols (35-40\% clay) and Red and Brown Ferrosols 
Table 1. Classification and key chemical properties of soils on which field and glasshouse experiments were established Properties of both surface soil $(0-0.1 \mathrm{~m})$ and subsoil $(0.3-0.4 \mathrm{~m})$ profile layers are shown for sites of field experiments, while the additional soil used in the glasshouse experiment was collected from the top $0.1 \mathrm{~m}$ of the profile

\begin{tabular}{|c|c|c|c|c|c|c|c|c|}
\hline \multirow[t]{2}{*}{ Site } & \multirow{2}{*}{$\begin{array}{l}\text { Depth } \\
\text { (m) }\end{array}$} & \multirow[t]{2}{*}{ Soil classification ${ }^{\mathrm{A}}$} & \multirow[t]{2}{*}{$\mathrm{pH}_{\mathrm{w}}$} & \multicolumn{5}{|c|}{ Exchangeable cations $(\mathrm{cmol}(+) / \mathrm{kg})$} \\
\hline & & & & $\mathrm{Ca}$ & $\mathrm{Mg}$ & K & $\mathrm{Na}$ & ECEC \\
\hline \multicolumn{9}{|c|}{ Soils used in incubation assay } \\
\hline BV1 & $0-0.1$ & Endo calcareous self mulching Black Vertosol & 6.8 & 21.6 & 27.2 & 0.50 & 0.51 & 49.8 \\
\hline BD1 & $0-0.1$ & Vertic eutrophic Brown Dermosol & 6.5 & 6.8 & 6.3 & 0.13 & 0.47 & 13.7 \\
\hline RF2 & $0-0.1$ & Haplic mesotrophic Red Ferrosol & 5.7 & 5.5 & 4.6 & 0.62 & 0.24 & 11.0 \\
\hline GV2 & $0-0.1$ & Endo hypersodic self mulching Grey Vertosol & 5.7 & 10.8 & 10.8 & 1.62 & 0.43 & 23.7 \\
\hline \multicolumn{9}{|c|}{$\mathrm{KCl}$ rate $\times$ incorporation method } \\
\hline \multicolumn{9}{|c|}{ Taabinga site } \\
\hline $\mathrm{BF} 1$ & $0-0.1$ & Manganic eutrophic Brown & 5.9 & 6.0 & 3.6 & 0.11 & 0.05 & 9.7 \\
\hline & $0.1-0.2$ & Ferrosol & 6.1 & 6.3 & 3.6 & 0.06 & 0.08 & 10.0 \\
\hline & $0.2-0.3$ & & 6.7 & 6.0 & 3.5 & 0.04 & 0.12 & 9.6 \\
\hline & $0.3-0.4$ & & 6.9 & 5.2 & 3.5 & 0.02 & 0.19 & 8.9 \\
\hline \multicolumn{9}{|c|}{ Wooroolin site } \\
\hline BV3 & $0-0.1$ & Endo calcareous self mulching & 6.5 & 31.5 & 24.8 & 0.39 & 0.68 & 57.3 \\
\hline & $0.1-0.2$ & Black Vertosol & 6.6 & 31.7 & 25.1 & 0.24 & 0.83 & 57.9 \\
\hline & $0.2-0.3$ & & 7.1 & 32.0 & 26.3 & 0.19 & 1.16 & 59.6 \\
\hline & $0.3-0.4$ & & 7.4 & 33.2 & 26.2 & 0.14 & 1.34 & 60.9 \\
\hline \multicolumn{9}{|c|}{$\mathrm{K}_{2} \mathrm{SO}_{4}$ profile mixing } \\
\hline \multicolumn{9}{|c|}{ Haly Creek site } \\
\hline \multirow[t]{4}{*}{ RF3 } & $0-0.1$ & Haplic mesotrophic Red Ferrosol & 7.1 & 10.0 & 2.4 & 0.75 & $<0.01$ & 13.1 \\
\hline & $0.1-0.2$ & & 6.0 & 5.4 & 2.5 & 0.17 & $<0.01$ & 8.1 \\
\hline & $0.2-0.3$ & & 5.5 & 2.5 & 2.2 & 0.08 & $<0.01$ & 5.4 \\
\hline & $0.3-0.5$ & & 5.5 & 1.6 & 2.7 & 0.06 & 0.04 & 4.3 \\
\hline \multicolumn{9}{|c|}{ Deep banding of mixtures of $\mathrm{KCl}$ and di-ammonium phosphate } \\
\hline \multirow[t]{2}{*}{ BV1 } & $0-0.1$ & Endo calcareous self mulching & 6.8 & 22.0 & 28.0 & 0.42 & 0.19 & 50.6 \\
\hline & $0.2-0.3$ & Black Vertosol & 7.6 & 26.0 & 32.0 & 0.12 & 0.76 & 58.9 \\
\hline \multirow[t]{2}{*}{ BV2 } & $0-0.1$ & Haplic self mulching Black & 8.1 & 21.0 & 14.0 & 0.32 & $<0.01$ & 35.3 \\
\hline & $0.2-0.3$ & Vertosol & 8.6 & 19.0 & 16.0 & 0.13 & 0.57 & 35.7 \\
\hline \multirow[t]{2}{*}{ GV1 } & $0-0.1$ & Endo hypersodic self mulching & 6.7 & 15.0 & 12.0 & 0.65 & 0.78 & 28.3 \\
\hline & $0.2-0.3$ & Grey Vertosol & 8.0 & 22.0 & 17.0 & 0.32 & 4.0 & 43.3 \\
\hline \multirow[t]{2}{*}{ BD1 } & $0-0.1$ & Vertic eutrophic Brown Dermosol & 6.5 & 6.5 & 3.8 & 0.15 & 0.08 & 10.9 \\
\hline & $0.2-0.3$ & & 7.9 & 6.9 & 11.0 & 0.05 & 1.9 & 19.9 \\
\hline \multirow[t]{2}{*}{ RF1 } & $0-0.1$ & Haplic eutrophic Red Ferrosol & 6.8 & 14.0 & 2.0 & 0.68 & 0.14 & 16.8 \\
\hline & $0.2-0.3$ & & 6.8 & 6.4 & 1.4 & 0.07 & 0.07 & 7.9 \\
\hline \multirow[t]{2}{*}{ RF2 } & $0-0.1$ & Haplic mesotrophic Red Ferrosol & 5.7 & 5.9 & 4.3 & 0.64 & $<0.01$ & 10.9 \\
\hline & $0.2-0.3$ & & 6.3 & 6.2 & 5.1 & 0.08 & $<0.01$ & 11.4 \\
\hline
\end{tabular}

Asbell (1996).

(50-65\% clay). Clay mineralogy was not determined on individual soils, but could be expected to vary between predominantly iron and aluminium oxyhydroxides and kaolinite (in Ferrosols and Dermosols) to predominantly smectite (montmorillonite and lesser amounts of illite) in the Black and Grey Vertosols (Gray and Murphy 1999; Bedrossian and Singh 2004).

\section{Incubation studies}

Soil was collected from the top $0.1 \mathrm{~m}$ at 4 sites representing the major cropping soils of the inland Burnett (BV1, BD1, GV2, RF2; Table 1), air-dried, passed through a 2-mm sieve, and placed in 150-mm-diameter pots in the glasshouse. Gravimetric moisture contents of subsamples of the air-dried soils were determined and the respective weights of oven-dry soil in pots of each soil type were calculated to be $1200 \mathrm{~g}$ (BV1 and
GV2), $1500 \mathrm{~g}$ (RF2), and $1900 \mathrm{~g}$ (BD1). $\mathrm{A} \mathrm{K}_{2} \mathrm{SO}_{4}$ solution $\left(86.0 \mathrm{~g} \mathrm{~K}_{2} \mathrm{SO}_{4} / \mathrm{L}\right)$ was used to apply 7 differential $\mathrm{K}$ rates to each of 4 replicate pots. Rates corresponded to $0,50,100,150$, 200,400 , and $800 \mathrm{~kg} \mathrm{~K} / \mathrm{ha}$, based on the area of the pot surface; this was equivalent to 0 to $\sim 1200 \mathrm{mg} \mathrm{K} / \mathrm{kg}$ air-dry soil (Table 2). Soils were thoroughly mixed, moistened to field capacity, and allowed to incubate in sealed plastic bags for 7 days before air drying.

At the end of the 7-day incubation period, subsamples of soil from each pot were collected for analysis of soil solution and exchangeable $\mathrm{K}$ and other cations. The remainder of the soil in the pots was allowed to dehydrate until soil weight was stable (i.e. soils were air-dry), and then soils were put through a succession of 5 wetting (to field capacity) and drying (to airdry) cycles over the ensuing 3-month period. During these cycles, temperatures in the glasshouse cycled between $33^{\circ} \mathrm{C}$ 
Table 2. Initial soil K status and ECEC $(\mathrm{cmol}(+) / \mathrm{kg})$ and the calculated impact of different rates of $\mathrm{K}$ addition on soil exchangeable $K$ status in the incubation assay in the glasshouse

$\mathrm{TBK}_{60}$, Tetraphenyl borate extractable $\mathrm{K}$, includes exchangeable $\mathrm{K}$

\begin{tabular}{|c|c|c|c|c|c|c|c|c|}
\hline \multirow[t]{2}{*}{ ECEC } & \multirow{2}{*}{$\begin{array}{c}\text { Initial } \\
\text { exch. K } \\
(\mathrm{cmol} / \mathrm{kg})\end{array}$} & \multirow{2}{*}{$\begin{array}{c}\text { Initial } \\
\mathrm{TBK}_{60} \\
(\mathrm{cmol} / \mathrm{kg})\end{array}$} & \multirow{2}{*}{$\begin{array}{l}\text { Soil wt } \\
\text { (g) }\end{array}$} & \multicolumn{3}{|c|}{ Rate of $\mathrm{K}$ addition } & \multicolumn{2}{|c|}{ Predicted final exch. K } \\
\hline & & & & $\mathrm{kg} / \mathrm{ha}$ & $\mathrm{mg} / \mathrm{kg}$ & $\mathrm{cmol} / \mathrm{kg}$ & $\mathrm{cmol} / \mathrm{kg}$ & $\%$ ECEC \\
\hline & & & & $B V 1$ & & & & \\
\hline \multirow[t]{8}{*}{49.8} & 0.50 & 0.52 & 1200 & 0 & 0 & 0 & 0.50 & 1.0 \\
\hline & & & & 50 & 73.7 & 0.19 & 0.69 & 1.4 \\
\hline & & & & 100 & 147.3 & 0.38 & 0.88 & 1.8 \\
\hline & & & & 150 & 220.9 & 0.57 & 1.07 & 2.1 \\
\hline & & & & 200 & 294.5 & 0.75 & 1.25 & 2.5 \\
\hline & & & & 400 & 589.1 & 1.51 & 2.01 & 4.0 \\
\hline & & & & 800 & 1178.1 & 3.01 & 3.51 & 7.1 \\
\hline & & & & $B D 1$ & & & & \\
\hline \multirow[t]{8}{*}{13.7} & 0.13 & 0.23 & 1900 & 0 & 0 & 0 & 0.13 & 0.9 \\
\hline & & & & 50 & 46.5 & 0.12 & 0.25 & 1.8 \\
\hline & & & & 100 & 93.0 & 0.24 & 0.37 & 2.7 \\
\hline & & & & 150 & 139.5 & 0.36 & 0.49 & 3.6 \\
\hline & & & & 200 & 186.0 & 0.48 & 0.61 & 4.4 \\
\hline & & & & 400 & 372.1 & 0.95 & 1.08 & 7.9 \\
\hline & & & & 800 & 744.1 & 1.90 & 2.03 & 14.8 \\
\hline & & & & $R F 2$ & & & & \\
\hline \multirow[t]{8}{*}{11.0} & 0.62 & 0.58 & 1500 & 0 & 0 & 0 & 0.62 & 5.6 \\
\hline & & & & 50 & 58.9 & 0.15 & 0.77 & 7.0 \\
\hline & & & & 100 & 117.8 & 0.30 & 0.92 & 8.4 \\
\hline & & & & 150 & 176.7 & 0.45 & 1.07 & 9.7 \\
\hline & & & & 200 & 235.6 & 0.60 & 1.22 & 11.1 \\
\hline & & & & 400 & 471.3 & 1.21 & 1.83 & 16.6 \\
\hline & & & & 800 & 942.5 & 2.41 & 3.03 & 27.5 \\
\hline & & & & $G V 2$ & & & & \\
\hline \multirow[t]{7}{*}{23.7} & 1.62 & 2.10 & 1200 & 0 & 0 & 0 & 1.62 & 6.8 \\
\hline & & & & 50 & 73.7 & 0.19 & 1.81 & 7.6 \\
\hline & & & & 100 & 147.3 & 0.38 & 2.00 & 8.4 \\
\hline & & & & 150 & 220.9 & 0.57 & 2.19 & 9.2 \\
\hline & & & & 200 & 294.5 & 0.75 & 2.37 & 10.0 \\
\hline & & & & 400 & 589.1 & 1.51 & 3.13 & 13.2 \\
\hline & & & & 800 & 1178.1 & 3.01 & 4.63 & 19.5 \\
\hline
\end{tabular}

(day) and $20^{\circ} \mathrm{C}$ (night). At the end of the final drying period, soils were ground $(<2 \mathrm{~mm})$ and analysed for exchangeable $\mathrm{K}$ and other cations.

\section{Field experiments}

There were 3 sets of field experiments undertaken during the period 1999-2007, with all except 1 experiment conducted for at least 2 consecutive crop seasons. In all except the Taabinga site, crops were dependent entirely on fallow soil moisture and in-crop rainfall. Rainfall records were kept for each site and season, soil moisture contents were determined at planting (to detect any adverse effects of $\mathrm{K}$ incorporation method on starting soil moisture), and, in the case of Haly Creek, profile soil moisture was monitored during the season using capacitance sensors and data loggers (viz. an Enviroscan ${ }^{\circledR}$ system).

Crop response to varying rates of $K$ application and levels of soil disturbance (Taabinga and Wooroolin sites)

Field experiments were established on a Brown Ferrosol at Taabinga and a Black Vertosol at Wooroolin (BF1, BV3;
Table 1) to investigate the interaction between $\mathrm{K}$ application rate and the depth and method of incorporation of $\mathrm{K}$ fertiliser in the soil profile on the availability of $\mathrm{K}$ to subsequent crops in soils with different CEC. The site at Wooroolin relied completely on in-season rainfall and stored soil moisture during the preceding fallow period, while the Taabinga site was able to utilise supplementary overhead irrigation during prolonged dry periods.

Each trial was established as a split-plot with 3 replicates. Main plots consisted of 3 depths of soil tillage/K fertiliser incorporation: (a) broadcasting onto the soil surface followed by shallow incorporation with offset discs to a depth of $0.10-0.12 \mathrm{~m}$; $(b)$ deep banding at $c .0 .3 \mathrm{~m}$ using a Yeoman ${ }^{\circledR}$ ripper with tines spaced at 0.35 -m intervals; and $(c)$ broadcasting followed by deep ploughing (profile inversion using a square plough) to a depth of c. $0.3 \mathrm{~m}$. Subplots were K application rates (applied as $\mathrm{KCl}$ ) equivalent to $0,50,100,175,350$, and $500 \mathrm{~kg} \mathrm{~K} / \mathrm{ha}$. Plot size varied with site: main plots were $120 \mathrm{~m}$ long and $10.8 \mathrm{~m}$ wide (Taabinga) or $102 \mathrm{~m}$ long and $7.3 \mathrm{~m}$ (Wooroolin), split into subplots that were each $20 \mathrm{~m}$ 
(Taabinga) or $17 \mathrm{~m}$ (Wooroolin) long with gaps of 2-3 m between subplots. In the 2006-07 crop season at Taabinga, main plots were split to 5.4-m-wide strips and sown to different crop species.

Crop sequences varied with site and treatments were applied during the winter preceding the first crop season at each location (i.e. 2003 at Taabinga and 2004 at Wooroolin). At Taabinga, the site was sown to maize (Zea mays L. cv. C79) in December 2003, soybean (Glycine max L. cv. Dragon) in December 2004, and peanut (Arachis hypogaea L. cv. VB97) in November 2005. In November 2006, main plots were split to accommodate alternate strips of maize (cv. Pioneer 3395 IR) and cotton (Gossypium hirsutum L. cv. SICOT 81). At Wooroolin, the crop sequence was sorghum (Sorghum bicolor L. Moench cv. MR Buster) sown in October 2004, barley (Hordeum vulgare cv. Tallon) sown in May 2005, maize sown in December 2005 (crop did not establish well and subsequently died of water stress), and sorghum (cv. MR Buster) sown in December 2006.

In order to avoid the confounding effects of ploughing on nutrient availability and to ensure that other nutrient deficiencies did not constrain growth (especially $\mathrm{N}, \mathrm{P}$, and Zn), all plots received luxury applications of nutrients other than $\mathrm{K}$ in subsequent crop seasons, either as preplanting applications broadcast and incorporated with offset discs, or as sidebanded applications made at sowing.

\section{Peanut crop response to $\mathrm{K}_{2} \mathrm{SO}_{4}$ applications with} varying levels of soil disturbance-Haly Creek

A site was established on a Red Ferrosol at Haly Creek (RF3, Table 1) prior to the $2000 / 01$ summer season to quantify the response to a common rate of applied $\mathrm{K}$ with varying degrees of incorporation into the top $0.3 \mathrm{~m}$ of the soil profile. Potassium fertiliser was applied as potassium sulfate $\left(\mathrm{K}_{2} \mathrm{SO}_{4}\right)$ at a rate to supply c. $180 \mathrm{~kg} \mathrm{~K} /$ ha during August 2000. The high application rate was chosen to enable detection of significant changes in exchangeable $\mathrm{K}$ in soil samples, and so that responses could potentially be followed over several seasons with high crop removal rates (residues of peanut crops are often removed as hay). The $\mathrm{K}$ fertilisers were broadcast onto the soil surface and (a) left unincorporated except for the soil disturbance during planting; (b) incorporated in the row area during strip tillage (a $0.3-\mathrm{m}$-wide strip, centred on the crop row, that was tilled using tined implements) to $0.25-0.3 \mathrm{~m}$ depth, but left on the surface in the inter-row area; $(c)$ incorporated by tines during a deep ripping operation to a depth of $0.25-0.3 \mathrm{~m}$; or $(d)$ incorporated using a plough to achieve profile inversion and mixing to $0.25-0.3 \mathrm{~m}$. Each treatment was applied in 4 replicated $100-\mathrm{m}$ strips adjoining the normal commercial practice on the farm, which was direct drilling with no applied $\mathrm{K}$ fertiliser. Treatments were applied following a failed wheat crop grown in the winter of 2000, and the site was sown to peanut (Arachis hypogaea cv. Streeton) in November 2000. The site was abandoned after the peanut crop due to a change in land use.

\section{Crop response to deep-banded $\mathrm{KCl}$ in the presence} of $N$ and $P$-Chelmsford

Six field trial sites were established prior to the 1999-2000 season in the Chelmsford district west of Wondai, in southern inland Queensland. Sites were representative of the main soil types used for rainfed cropping in the district, and were chosen in consultation with the local grower group after commercial soil tests had shown either low soil exchangeable $\mathrm{K}$ per se, or soil exchangeable $\mathrm{K}$ reserves that were strongly stratified in the top $0.1 \mathrm{~m}$ of the profile. Soil classification and key properties associated with soil cation supply are shown in Table 1.

Each site had 2 replicated strips, each $60 \mathrm{~m}$ long and 10 summer crop rows wide $(9-10 \mathrm{~m}$, depending on crop species) of each of 3 common treatments: $(a)$ the current farmer practice (which varied with crop species and had $0-86 \mathrm{~kg} \mathrm{~N}, 0-43 \mathrm{~kg} \mathrm{P}$, and $0-81 \mathrm{~kg} \mathrm{~K} / \mathrm{ha}$, all applied into the top $0.10 \mathrm{~m}$ of the soil profile as bands or broadcast and incorporated); (b) deep-banded di-ammonium phosphate (DAP) to supply an additional $20 \mathrm{~kg} \mathrm{~N}$ and $25 \mathrm{~kg} \mathrm{P} / \mathrm{ha}$; and (c) a deep-banded commercial blend of DAP and $\mathrm{KCl}$ to supply an additional $20 \mathrm{~kg} \mathrm{~N}, 25 \mathrm{~kg} \mathrm{P}$, and $80 \mathrm{~kg} \mathrm{~K} / \mathrm{ha}$. Extra treatments were included at individual sites in response to grower interest. These included broadcasting the same rates of the $\mathrm{DAP} / \mathrm{KCl}$ blend well in advance of planting and shallow mixing with offset discs or scarifiers (RF2), or applying varying rates of $\mathrm{KCl}(100$, 200 , and $400 \mathrm{~kg} \mathrm{KCl} / \mathrm{ha}$ ) applied with a scarifier during land preparation (BV1).

The deep banding was undertaken with the same tillage equipment as described in the deep banding treatments at the Taabinga and Wooroolin sites, with the deep bands spaced $0.35 \mathrm{~m}$ apart at a depth of $c .0 .3 \mathrm{~m}$. The deep-banding treatments were designed as a practical strategy to overcome stratified $\mathrm{K}$ reserves without profile inversion and mixing (i.e. ploughing). Sites were sown to maize, sorghum, or soybeans in year 1, and peanuts, soybeans, cotton, and sorghum in year 2 .

\section{Soil analyses}

Soil samples were collected to characterise each site using standard analytical methods (Rayment and Higginson 1992). Effective CEC (ECEC) was determined as the sum of exchangeable cations plus exchangeable acidity. Specifically, exchangeable cations were determined by shaking $4 \mathrm{~g}(<2 \mathrm{~mm})$ soil in $80 \mathrm{~mL}$ of $1 \mathrm{M} \mathrm{NH}_{4} \mathrm{Cl}$ (adjusted to $\mathrm{pH} 7$ but unbuffered) for $1 \mathrm{~h}$, centrifuging (20 min at RCF $2000 \mathrm{G}$ ), and determining cation concentration in the solution by ICPAES. Additional measures of soil $\mathrm{K}$ pools were undertaken by determining tetraphenyl borate extractable $\mathrm{K}$ following the procedure of Carey et al. (2000), using a $60 \mathrm{~min}$ extraction time $\left(\mathrm{TBK}_{60}\right)$. Differences between $\mathrm{TBK}_{60}$ and exchangeable $\mathrm{K}$ were used as an indicator of potentially plant-available $\mathrm{K}$ sources in either the 'fixed' or 'structural' K pools (Moody and Bell 2006).

After the 7-day incubation period in the glasshouse assay, a subsample of soil was used to determine exchangeable cations $(\mathrm{Na}, \mathrm{K}, \mathrm{Mg}$, and $\mathrm{Ca}$ ) and the recovery of added $\mathrm{K}$ in the exchangeable $\mathrm{K}$ fraction was determined. Soil solution cations were then determined after rewetting, equilibration, and centrifugation. The ionic strength of the soil solution was determined using the method of Menzies and Bell (1988) and the activity ratio of $K$ in the soil solution $\left(A R_{K}\right.$, a measure of the intensity of $\mathrm{K}$ supply) was determined using the extended Debye-Hückel equation (Barber 1985). The amount of $\mathrm{K}$ that had to be added to cause a measured change in $\mathrm{AR}_{\mathrm{K}}$ was used as 
an indicator of the relative $\mathrm{K}$ buffer capacities of each soil type (Bedrossian and Singh 2004).

To determine the impact of $\mathrm{K}$ application rate and depth of incorporation on $\mathrm{K}$ distribution in the field trials, samples were collected from each plot (except in the deep-banded treatments, due to difficulties associated with relocating the position of the bands) either 1 month after crop establishment (Haly Creek) or following the harvest of the first crop in the crop cycle (Taabinga and Wooroolin). In the latter 2 sites, soil samples were then collected annually before sowing of the next crop in the rotation. At each sampling time, at least 4 separate soil cores were collected from each plot to depths of $0.4-0.5 \mathrm{~m}$, with soil from each 0.1-m increment bulked to provide a sample from each plot.

\section{Crop measurements_biomass, $K$ uptake and removal}

In each of the field experiments, plant samples were collected during the season, with at least 1 sample date at the appropriate growth stage for each crop corresponding to maximum crop biomass. Sampling was conducted from randomly selected sites within each plot (areas of $1-2 \mathrm{~m}^{2}$, depending on inter-row spacing and experiment) with at least 2 duplicate samples taken within each replicate plot or strip. The availability of soil $\mathrm{K}$ in the various treatments was assessed by calculating the $\mathrm{K}$ uptake at maximum crop biomass. Sample dry weight was determined after $48-72 \mathrm{~h}$ forced-draft dehydration at $70^{\circ} \mathrm{C}$, and the plant material was ground and analysed for $\mathrm{Ca}, \mathrm{Mg}$, and $\mathrm{K}$ using X-ray fluorescence.

Crop yields were determined by mechanical harvesting. In-field weigh bins were used to determine yields from the large treatment strips in the Chelmsford and Haly Creek studies, with 2 yield samples determined from strips harvested from the entire plot length in each replicate. In the Taabinga and Wooroolin studies, small plot harvesters were used and samples were bagged and weighed separately. In all experiments, subsamples of grains/pods/seed+lint were collected to determine grain weights, quality, and crop value, as well as for chemical analysis to determine $\mathrm{K}$ and other nutrient concentrations on a dry-weight basis. Calculations were made to determine crop $\mathrm{K}$ recovery (additional $\mathrm{K}$ in the crop/fertiliser $\mathrm{K}$ applied), $\mathrm{K}$ balance $[\mathrm{K}$ added in fertiliser $-\mathrm{K}$ removed in grain/(shell+kernel)/(seed+lint)], and also the amount of redistribution of $\mathrm{K}$ into surface soil layers in stubbles/residues (the difference between crop $\mathrm{K}$ content of the maximum biomass sample and the $\mathrm{K}$ removed in harvested produce).

\section{Statistical analysis}

Standard analysis of variance techniques were used to assess the impact of treatments in both field and laboratory studies using the GEnstat statistical package. Least-squares linear regressions were used to describe relationships between soil $\mathrm{K}$ concentration and the rate of $\mathrm{K}$ applied ( $\mathrm{K}$ recovery) and between $\mathrm{AR}_{\mathrm{K}}$ and the exchangeable K expressed as a proportion of the total ECEC (\%) in the incubation study. Non-linear regression techniques were used to describe the relationship between soil $\mathrm{K}$ concentration and crop $\mathrm{K}$ uptake.

\section{Results}

Incubation studies

Despite the differences in soil type and the presence of other $\mathrm{K}$ pools that potentially could represent sinks for applied $\mathrm{K}$ fertiliser (i.e. $\mathrm{TBK}_{60}$ - exchangeable $\mathrm{K}$ in both $\mathrm{BD} 1$ and GV2; Table 2), the exchangeable K pool contained $92-98 \%$ of the applied $\mathrm{K}$ fertiliser after the 7-day incubation. More importantly, even after the series of wetting and drying cycles conducted over the following 3-month period, there was no evidence of a reduction in the exchangeable K pool (Fig. 1), even in the soils receiving the highest rates of $\mathrm{K}$ addition and in which exchangeable K represented much higher proportions of the total ECEC than in their original condition (Table 2).

The impact of increasing rates of $\mathrm{K}$ fertiliser addition on soil solution $\mathrm{K}$ concentration (a measure of the intensity of K supply)

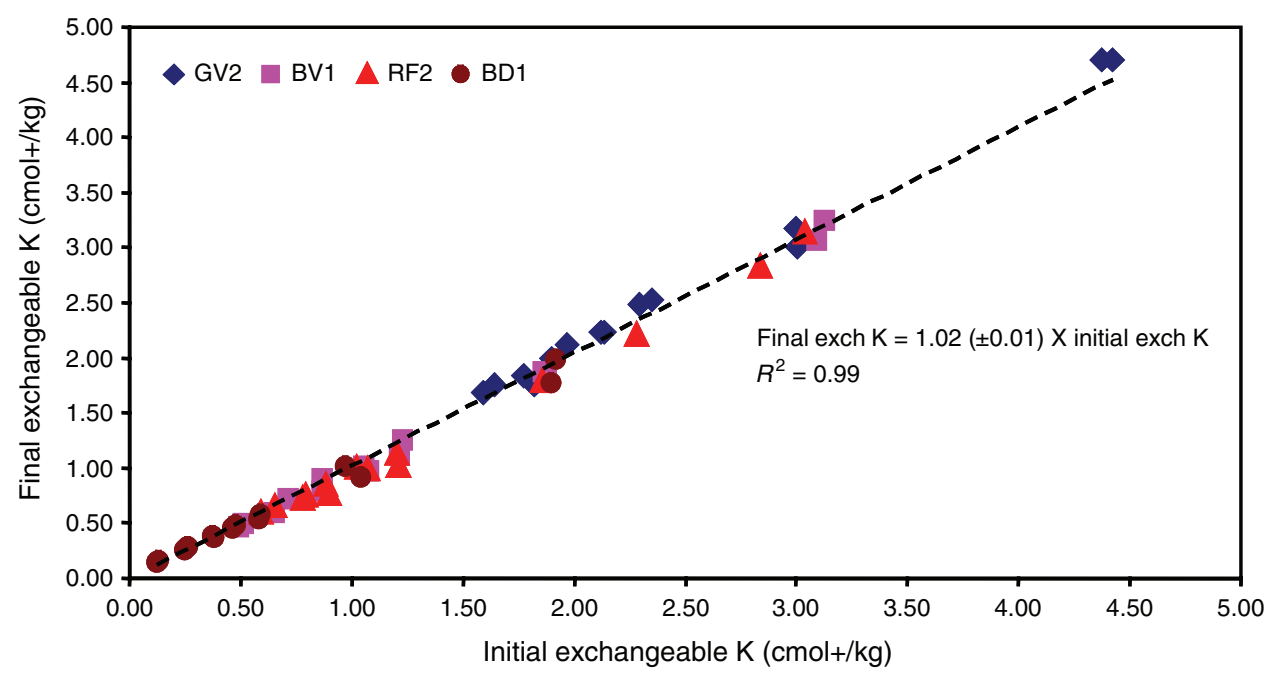

Fig. 1. Initial exchangeable $\mathrm{K}(\mathrm{cmol}(+) / \mathrm{kg})$ in soils after the 7-day incubation at field capacity compared with that measured after 3 months of wetting and drying. The variation in exchangeable $\mathrm{K}$ in each soil type was the result of applications of $\mathrm{K}$ fertiliser shown in Table 2. 
in the different soil types was considered in relation to both the size of the exchangeable $\mathrm{K}$ pool with which it is considered to be in rapid equilibrium (Fig. $2 a$ ), and the exchangeable K expressed as a percentage of the ECEC (Fig. $2 b$ ). The latter was done in an attempt to consider variation in soil solution $\mathrm{K}$ in the absence of confounding effects of differing quantities of exchangeable cations.

The relationship between soil solution $\mathrm{K}$ concentration and exchangeable $\mathrm{K}$ showed marked differences between soil types (Fig. 2a). Background solution $\mathrm{K}$ concentrations were very low in the Brown Dermosol (BD1, 6.5 mg K/L) and the Black Vertosol (BV1, $9.4 \mathrm{mg} \mathrm{K} / \mathrm{L}$ ), low in the Red Ferrosol (RF2, $49.1 \mathrm{mg} \mathrm{K} / \mathrm{L}$ ), but relatively high in the Grey Vertosol (GV2, $136.2 \mathrm{mg} \mathrm{K} / \mathrm{L}$ ). These initial differences were confounded by contrasting rates of increase in soil solution $\mathrm{K}$ with $\mathrm{K}$ fertiliser

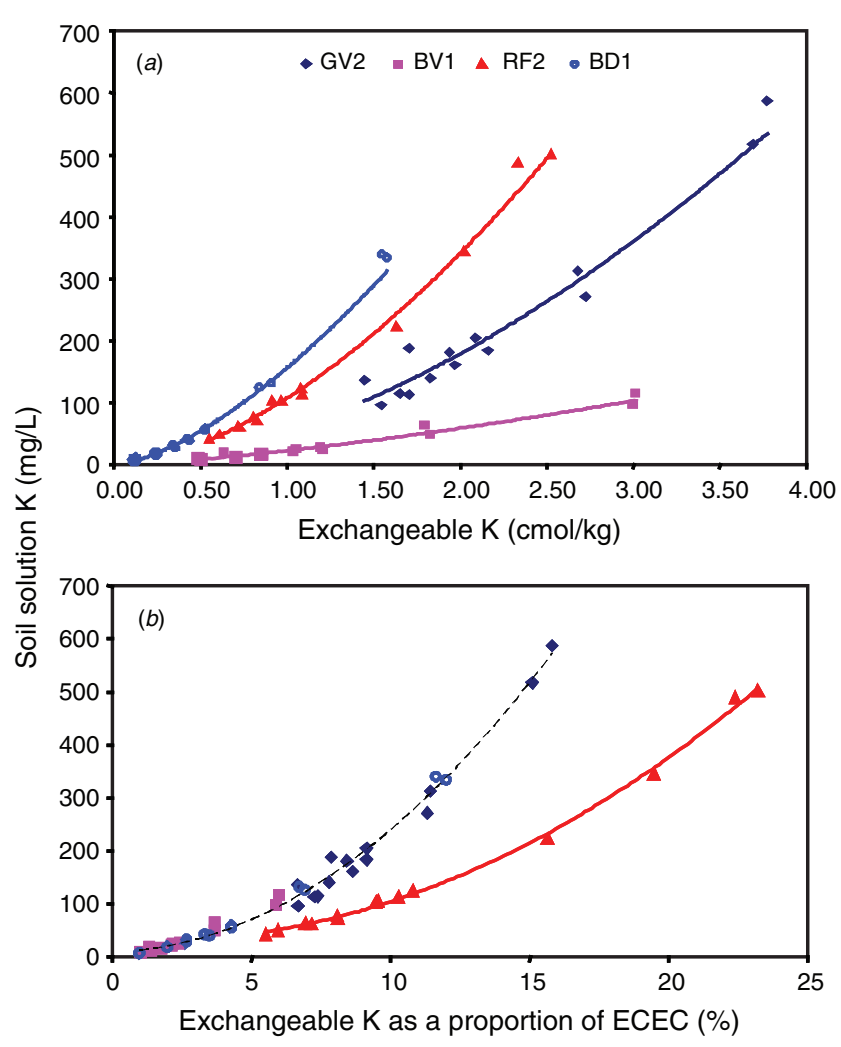

Fig. 2. Relationships between the concentration of $\mathrm{K}$ in the soil solution after a 7-day incubation at field capacity and either (a) exchangeable $\mathrm{K}$ concentration per se, or $(b)$ exchangeable $\mathrm{K}$ concentration expressed as a percentage of the ECEC. Data are shown for a Black (BV1) and Grey (GV2) Vertosol, a Red Ferrosol (RF2) and a Brown Dermosol (BD1) from the incubation study. In $(a)$, equations describing the fitted relationship between exchangeable $\mathrm{K}$ concentration and soil solution $\mathrm{K}$ concentration were as follows: solution $\mathrm{K}_{\mathrm{BV} 1}=22.50 \times$ exchangeable $\mathrm{K}^{1.388}\left(R^{2}=0.95\right)$; solution $\quad \mathrm{K}_{\mathrm{GV} 2}=54.32 \times$ exchangeable $\quad \mathrm{K}^{1.723} \quad\left(R^{2}=0.92\right) ; \quad$ solution $\mathrm{K}_{\mathrm{RF} 2}=107.84 \times$ exchangeable $\quad \mathrm{K}^{1.664} \quad\left(R^{2}=0.99\right) ;$ solution $\quad \mathrm{K}_{\mathrm{BD} 1}=$ $156.40 \times$ exchangeable $\mathrm{K}^{1.519}\left(R^{2}=0.99\right)$. In $(b)$, equations describing the fitted relationship between the percentage of ECEC occupied by exchangeable $\mathrm{K}$ and soil solution $\mathrm{K}$ concentration were as follows: solution $\mathrm{K}_{(\mathrm{BV} 1, \mathrm{GV} 2, \mathrm{BD} 1)}=2.17 \times(\text { exchange } \mathrm{K})^{2}+1.33 \times($ exchange $\mathrm{K})+$ $9.37 \quad\left(R^{2}=0.99\right) ; \quad$ solution $\quad \mathrm{K}_{\mathrm{RF} 2}=1.01 \times(\text { exchange } \mathrm{K})^{2}-2.96 \times$ (exchange $\mathrm{K})+33.15\left(R^{2}=0.99\right)$. addition. Noteworthy was the much slower rate of increase in soil solution $\mathrm{K}$ with increases in the exchangeable $\mathrm{K}$ pool in the BV1 soil.

Some of the apparent differences between soil types in the relationship between solution $\mathrm{K}$ concentration and exchangeable $\mathrm{K}$ disappeared when solution $\mathrm{K}$ concentration was plotted as a function of the percentage of the soil ECEC occupied by $\mathrm{K}$ (K saturation, Fig. $2 b$ ). While there was only limited overlap in the range of $\mathrm{K}$ saturation between BV1 and GV2 data, there appeared to be a common curvilinear relationship that could predict soil solution K concentration for BV1, GV2, and BD1. This relationship was distinctly different from that derived for $\mathrm{RF} 2$, in which solution $\mathrm{K}$ concentration increased much more slowly in response to increases in $\mathrm{K}$ saturation.

The relationship between the size of the exchangeable $\mathrm{K}$ pool and the activity of $K$ in the soil solution $\left(A R_{K}\right)$ also varied markedly between soil types. This relationship is shown in Fig. 3, with the analysis restricted to the linear portion of the response curve. This was equivalent to application rates ranging from 0 to $200 \mathrm{~kg} \mathrm{~K} / \mathrm{ha}$, and spans the range normally encountered in field situations. The rate of change in exchangeable $\mathrm{K}$ with changes in $\mathrm{AR}_{\mathrm{K}}$ (i.e. an indicator of $\mathrm{K}$ buffering capacity, $\mathrm{KBC}$, and measured by the slopes of the regressions shown in Fig. 3) varied significantly with soil type, with $\mathrm{BV} 1>\mathrm{GV} 2$ and $\mathrm{BD} 1>\mathrm{RF} 2$. These data, in combination with Fig. $2 a$, show that much higher rates of $\mathrm{K}$ fertiliser addition will be needed to significantly alter the intensity of $\mathrm{K}$ supply in the Black Vertosol, while the opposite is the case for the Red Ferrosol.

\section{Field studies involving rates of applied $\mathrm{KCl}$ fertiliser and degree of mixing}

\section{Impact on exchangeable $K$}

The effect of the different rates of applied $\mathrm{K}$ fertiliser and the method of incorporation (i.e. shallow discing cf. profile inversion with a plough) on exchangeable $\mathrm{K}$ in the top $0.4 \mathrm{~m}$ of the soil profile is shown for the Brown Ferrosol at Taabinga (BF1) and the Black Vertosol at Wooroolin (BV3) in Table 3. Data represented the net effect of fertiliser and tillage treatments modified by removal in harvested grain and redistribution in surface-retained crop residue in the first crop year.

There were generally significant interactions between tillage/degree of mixing and $\mathrm{K}$ fertiliser rate at both sites in the top $0.3 \mathrm{~m}$ of the profile, with small but significant effects of both rate and tillage also recorded in the $0.3-0.4 \mathrm{~m}$ layer at Taabinga. Exchangeable $\mathrm{K}$ increased with increasing $\mathrm{K}$ application rate, with the majority of the $\mathrm{K}$ recovered in the $0.1 \mathrm{~m}$ layer in the shallow discing treatments but distributed more evenly in the top $0.2-0.3 \mathrm{~m}$ in the ploughed treatments (Table 3). However, the more uniform distribution arising from profile mixing in the ploughed treatments was rapidly negated in the subsequent cropping seasons, with a comparison of profile distribution of $\mathrm{K}$ (for $\mathrm{K}$ rates $\geq 100 \mathrm{~kg} \mathrm{~K} / \mathrm{ha}$ ) at the beginning and end of the monitoring period for the ploughed treatments showing relative enrichment of the $0-0.1 \mathrm{~m}$ layer and depletion of the $0.1-0.2$ and $0.2-0.3 \mathrm{~m}$ layers (Table 4 ). 


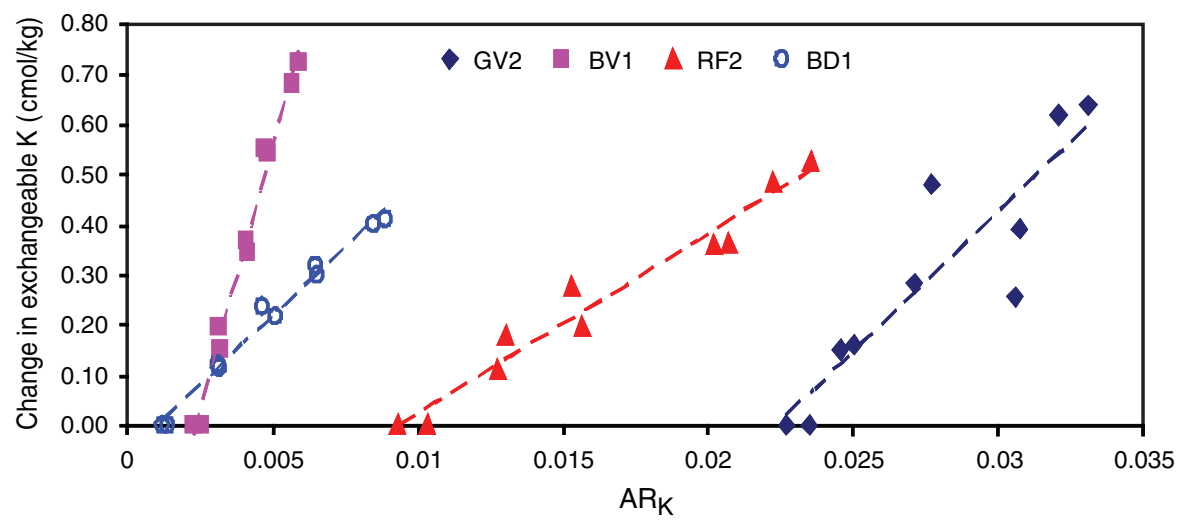

Fig. 3. Relationship between the change in exchangeable $\mathrm{K}$ with fertiliser $\mathrm{K}$ addition and the activity of $\mathrm{K}$ in the soil solution $\left(\mathrm{AR}_{\mathrm{K}}\right)$ for contrasting soil types in the incubation study. Slopes of the fitted regression lines were: $55.7 \pm 9.6\left(\mathrm{GV} 2, R^{2}=0.81\right), 212.7 \pm 8.6\left(\mathrm{BV} 1, R^{2}=0.99\right), 35.8 \pm 2.5\left(\mathrm{RF} 2, R^{2}=0.96\right)$, and $54.7 \pm 2.4\left(\mathrm{BD} 1, R^{2}=0.98\right)$.

\section{Accumulation of $K$ in crop biomass and removal in harvested product}

There were no significant effects of $\mathrm{K}$ application rate on biomass production of any crop at Wooroolin, and significant responses were confined to the final crop season (maize and cotton) at Taabinga, in which biomass production increased by an average of $22 \%$ at rates $\geq 100 \mathrm{~kg} \mathrm{~K} / \mathrm{ha}$. There were also no significant differences between $\mathrm{K}$ application methods, or

Table 3. Effect of $K$ rate and depth of incorporation on soil exchangeable $\mathrm{K}$ after harvest of the first crop c. 9 months after $\mathrm{K}$ fertiliser application at the Taabinga site (Brown Ferrosol) and the Wooroolin site (Black Vertosol)

OD, Offset disc; DP, deep plough. n.s., Not significant $(P>0.05)$

\begin{tabular}{lcccccccc}
\hline K rate & \multicolumn{9}{c}{$0-0.1 \mathrm{~m}$} & \multicolumn{3}{c}{$0.1-0.2 \mathrm{~m}$} & \multicolumn{2}{c}{$0.2-0.3 \mathrm{~m}$} & \multicolumn{2}{c}{$0.3-0.4 \mathrm{~m}$} \\
$(\mathrm{~kg} / \mathrm{ha})$ & OD & DP & OD & DP & OD & DP & OD & DP \\
\hline \multicolumn{8}{c}{ Taabinga } \\
0 & 0.11 & 0.08 & 0.06 & 0.06 & 0.04 & 0.06 & 0.02 & 0.03 \\
50 & 0.14 & 0.10 & 0.08 & 0.07 & 0.05 & 0.05 & 0.03 & 0.03 \\
100 & 0.19 & 0.12 & 0.07 & 0.11 & 0.04 & 0.09 & 0.03 & 0.04 \\
175 & 0.23 & 0.16 & 0.13 & 0.16 & 0.04 & 0.09 & 0.03 & 0.05 \\
350 & 0.38 & 0.24 & 0.17 & 0.27 & 0.07 & 0.31 & 0.04 & 0.10 \\
500 & 0.51 & 0.34 & 0.32 & 0.52 & 0.11 & 0.40 & 0.06 & 0.11
\end{tabular}

\begin{tabular}{|c|c|c|c|c|c|c|c|c|}
\hline \multicolumn{9}{|l|}{ 1.s.d. $(P=0.05)$} \\
\hline Rate (R) & \multicolumn{2}{|c|}{0.09} & \multicolumn{2}{|c|}{0.07} & \multicolumn{2}{|c|}{0.07} & \multicolumn{2}{|c|}{0.01} \\
\hline Tillage (T) & \multicolumn{2}{|c|}{ n.s. } & \multicolumn{2}{|c|}{ n.s. } & \multicolumn{2}{|c|}{0.10} & \multicolumn{2}{|c|}{0.03} \\
\hline $\mathrm{R} \times \mathrm{T}$ & \multicolumn{2}{|c|}{ n.s. } & \multicolumn{2}{|c|}{0.15} & \multicolumn{2}{|c|}{0.10} & \multicolumn{2}{|c|}{ n.s. } \\
\hline \multicolumn{9}{|c|}{ Wooroolin } \\
\hline 0 & 0.45 & 0.35 & 0.25 & 0.25 & 0.17 & 0.20 & 0.14 & 0.16 \\
\hline 50 & 0.47 & 0.37 & 0.22 & 0.31 & 0.13 & 0.21 & 0.12 & 0.16 \\
\hline 100 & 0.50 & 0.38 & 0.23 & 0.29 & 0.11 & 0.25 & 0.14 & 0.18 \\
\hline 175 & 0.67 & 0.49 & 0.31 & 0.47 & 0.16 & 0.25 & 0.12 & 0.16 \\
\hline 350 & 0.77 & 0.53 & 0.32 & 0.54 & 0.15 & 0.25 & 0.12 & 0.15 \\
\hline 500 & 0.99 & 0.65 & 0.34 & 0.64 & 0.17 & 0.38 & 0.16 & 0.29 \\
\hline \multicolumn{9}{|l|}{ 1.s.d. $(P=0.05)$} \\
\hline Rate & \multicolumn{2}{|c|}{0.07} & \multicolumn{2}{|c|}{0.08} & \multicolumn{2}{|c|}{0.09} & \multicolumn{2}{|c|}{ n.s. } \\
\hline Tillage & \multicolumn{2}{|c|}{0.18} & \multicolumn{2}{|c|}{0.03} & \multicolumn{2}{|c|}{0.07} & \multicolumn{2}{|c|}{ n.s. } \\
\hline $\mathrm{R} \times \mathrm{T}$ & \multicolumn{2}{|c|}{0.14} & \multicolumn{2}{|c|}{0.10} & \multicolumn{2}{|c|}{0.12} & \multicolumn{2}{|c|}{ n.s. } \\
\hline
\end{tabular}

interactions between incorporation method and $\mathrm{K}$ rate, at either site. Average biomass production in the nil $\mathrm{K}$ treatments was $5450 \mathrm{~kg} / \mathrm{ha}$ (maize crop 1), $8350 \mathrm{~kg} / \mathrm{ha}$ (soybean crop 2), $8050 \mathrm{~kg} / \mathrm{ha}$ (peanut crop 3), $7000 \mathrm{~kg} / \mathrm{ha}$ (cotton crop 4), and $10050 \mathrm{~kg} / \mathrm{ha}$ (maize crop 4) at Taabinga. At Wooroolin, average biomass production in the nil K treatments was $11950 \mathrm{~kg} / \mathrm{ha}$ (sorghum crop 1), $7450 \mathrm{~kg} / \mathrm{ha}$ (barley crop 2), and $9350 \mathrm{~kg} / \mathrm{ha}$ (sorghum crop 3).

Accumulation of $\mathrm{K}$ in crop biomass was similarly unaffected by incorporation method or interactions between incorporation method and application rate. However, there were large and significant responses in crop $\mathrm{K}$ accumulation in response to $\mathrm{K}$ application rate in all crops at Taabinga, and smaller but often significant responses at Wooroolin (Table 5). Accumulation of $\mathrm{K}$ in biomass increased up to 4-fold with increasing $\mathrm{K}$ rate at Taabinga (maize in crop year 4) and there was always at least a 2 -fold increase in biomass $\mathrm{K}$ accumulation (despite the lack of significant biomass responses). At Wooroolin, however, the greatest increase in $\mathrm{K}$ accumulation in biomass (sorghum in crop year 4) was still $<30 \%$.

Similar to biomass production, the only significant differences in yields of harvested product (grain, kernel, or seed+lint) were in response to $K$ rate in crop year 4 at Taabinga, where maize yields increased by up to $20 \%$ ( $\mathrm{K}$ rates $\geq 100 \mathrm{~kg} / \mathrm{ha}$ ) and cotton yields increased consistently to plateau at $85-90 \%$ higher than the control treatments for $\mathrm{K}$ treatments $\geq 350 \mathrm{~kg} / \mathrm{ha}$ (data not shown).

Unlike $\mathrm{K}$ concentration in the biomass, the $\mathrm{K}$ concentration in the harvested product was relatively unaffected by $\mathrm{K}$ fertiliser rates and crop $\mathrm{K}$ accumulation. There were no significant differences in grain $\mathrm{K}$ concentrations at Wooroolin (sorghum $\mathrm{K}$ averaged $0.31 \% \mathrm{~K}$ in year 1 and $0.33 \% \mathrm{~K}$ in year 4 , and barley $\mathrm{K}$ averaged $0.63 \% \mathrm{~K}$ ), while differences at Taabinga were either not significant (average maize $\mathrm{K}$ in year 1 was $0.28 \%$ ) or increased by small amounts at higher $\mathrm{K}$ rates. These increases ranged from 1.59 to $1.72 \% \mathrm{~K}$ in soybean grain in year 2 , from 0.62 to $0.75 \% \mathrm{~K}$ in peanut pods in year 3 (with most increase in the shell rather than the peanut kernel), and from 
Table 4. Change in exchangeable $\mathrm{K}$ concentrations $(\mathrm{cmol}(+) / \mathrm{kg})$ in the top $0.4 \mathrm{~m}$ of the soil profile of the deepploughed treatments with initial $K$ application rates $>100 \mathrm{~kg} / \mathrm{ha}$ at Taabinga (BF1) and Wooroolin (BV3) over the experimental period

These changes occurred between crop 1 and crop 5 (Taabinga) or between crop 1 and crop 4 (Wooroolin). n.s., Not significant $(P>0.05)$

\begin{tabular}{|c|c|c|c|c|c|c|c|c|}
\hline \multirow{2}{*}{$\begin{array}{l}\mathrm{K} \text { rate } \\
(\mathrm{kg} / \mathrm{ha})\end{array}$} & \multicolumn{2}{|c|}{$0-0.1 \mathrm{~m}$} & \multicolumn{2}{|c|}{$0.1-0.2 \mathrm{~m}$} & \multicolumn{2}{|c|}{$0.2-0.3 \mathrm{~m}$} & \multicolumn{2}{|c|}{$0.3-0.4 \mathrm{~m}$} \\
\hline & Crop 1 & Crop 5 & Crop 1 & Crop 5 & Crop 1 & Crop 5 & Crop 1 & Crop 5 \\
\hline \multicolumn{9}{|c|}{ Taabinga } \\
\hline 100 & 0.12 & 0.24 & 0.07 & 0.12 & 0.09 & 0.06 & 0.04 & 0.05 \\
\hline 175 & 0.16 & 0.27 & 0.16 & 0.13 & 0.09 & 0.07 & 0.05 & 0.04 \\
\hline 350 & 0.17 & 0.31 & 0.31 & 0.17 & 0.29 & 0.10 & 0.10 & 0.06 \\
\hline 500 & 0.33 & 0.42 & 0.67 & 0.28 & 0.40 & 0.18 & 0.11 & 0.12 \\
\hline \multicolumn{9}{|c|}{ 1.s.d. $(P=0.05)$} \\
\hline Rate (R) & \multicolumn{2}{|c|}{0.06} & \multicolumn{2}{|c|}{0.04} & \multicolumn{2}{|c|}{0.04} & \multicolumn{2}{|c|}{0.02} \\
\hline Time (T) & \multicolumn{2}{|c|}{0.03} & \multicolumn{2}{|c|}{0.03} & \multicolumn{2}{|c|}{0.02} & \multicolumn{2}{|c|}{ n.s. } \\
\hline $\mathrm{R} \times \mathrm{T}$ & \multicolumn{2}{|c|}{ n.s. } & \multicolumn{2}{|c|}{0.06} & \multicolumn{2}{|c|}{0.06} & \multicolumn{2}{|c|}{ n.s. } \\
\hline \multicolumn{9}{|c|}{ Wooroolin } \\
\hline 100 & 0.38 & 0.77 & 0.29 & 0.22 & 0.25 & 0.15 & 0.18 & 0.15 \\
\hline 175 & 0.43 & 0.79 & 0.45 & 0.24 & 0.27 & 0.14 & 0.17 & 0.16 \\
\hline 350 & 0.53 & 0.67 & 0.54 & 0.34 & 0.25 & 0.16 & 0.15 & 0.16 \\
\hline 500 & 0.65 & 0.87 & 0.64 & 0.5 & 0.38 & 0.20 & 0.29 & 0.16 \\
\hline \multicolumn{9}{|c|}{ 1.s.d. $(P=0.05)$} \\
\hline Rate & \multicolumn{2}{|c|}{0.09} & \multicolumn{2}{|c|}{0.05} & \multicolumn{2}{|c|}{ n.s. } & \multicolumn{2}{|c|}{ n.s. } \\
\hline Time & \multicolumn{2}{|c|}{0.07} & \multicolumn{2}{|c|}{0.03} & \multicolumn{2}{|c|}{0.03} & \multicolumn{2}{|c|}{ n.s. } \\
\hline $\mathrm{R} \times \mathrm{T}$ & \multicolumn{2}{|c|}{0.15} & \multicolumn{2}{|c|}{ n.s. } & \multicolumn{2}{|c|}{ n.s. } & \multicolumn{2}{|c|}{ n.s. } \\
\hline
\end{tabular}

Table 5. Accumulation of $\mathrm{K}$ in above ground biomass in response to increasing $\mathrm{K}$ fertiliser application rates for the sequence of crops grown at Taabinga and Wooroolin

The maize sown in crop year 3 at Wooroolin did not establish. Values in parentheses indicate the proportion of biomass K that was removed in the harvested product (KHI). n.a., Not applicable

\begin{tabular}{|c|c|c|c|c|c|}
\hline $\mathrm{K}$ rate $(\mathrm{kg} / \mathrm{ha})$ & Crop Year 1 & Crop Year 2 & Crop Year 3 & \multicolumn{2}{|c|}{ Crop Year 4} \\
\hline \multicolumn{6}{|c|}{ Taabinga } \\
\hline & Maize & Soybean & Peanut & Maize & Cotton \\
\hline 0 & $40.8(0.36)$ & $56.6(0.77)$ & $47.9(0.48)$ & $36.3(0.39)$ & $39.9(0.24)$ \\
\hline 50 & $55.1(0.28)$ & $79.0(0.57)$ & $61.1(0.40)$ & $48.8(0.30)$ & $49.0(0.25)$ \\
\hline 100 & $60.6(0.25)$ & $99.6(0.47)$ & $76.7(0.34)$ & $71.4(0.25)$ & $64.9(0.24)$ \\
\hline 175 & $74.7(0.21)$ & $104.3(0.44)$ & $88.4(0.30)$ & $83.0(0.21)$ & $73.8(0.22)$ \\
\hline 350 & $78.9(0.19)$ & $114.3(0.40)$ & $107.5(0.26)$ & $116.6(0.15)$ & $100.2(0.19)$ \\
\hline 500 & $83.7(0.18)$ & $119.6(0.39)$ & $111.5(0.26)$ & $144.1(0.12)$ & $131.3(0.15)$ \\
\hline 1.s.d. $(P=0.05)$ & $8.0(0.05)$ & $12.9(0.06)$ & $9.7(0.05)$ & & \\
\hline \multicolumn{6}{|c|}{ Wooroolin } \\
\hline & Sorghum & Barley & Maize & \multicolumn{2}{|c|}{ Sorghum } \\
\hline 0 & $127.9(0.16)$ & $88.6(0.09)$ & n.a. & \multicolumn{2}{|c|}{$102.6(0.13)$} \\
\hline 50 & $130.9(0.17)$ & $94.9(0.08)$ & n.a. & \multicolumn{2}{|c|}{$112.4(0.11)$} \\
\hline 100 & $142.4(0.15)$ & $95.2(0.08)$ & n.a. & \multicolumn{2}{|c|}{$113.3(0.10)$} \\
\hline 175 & $146.0(0.14)$ & $112.1(0.07)$ & n.a. & \multicolumn{2}{|c|}{$114.3(0.11)$} \\
\hline 350 & $169.6(0.13)$ & $103.4(0.07)$ & n.a. & \multicolumn{2}{|c|}{$120.9(0.09)$} \\
\hline 500 & $150.8(0.14)$ & $108.5(0.07)$ & n.a. & \multicolumn{2}{|c|}{$132.3(0.09)$} \\
\hline 1.s.d. $(P=0.05)$ & n.s. (n.s.) & 14.8 (n.s.) & n.a. & \multicolumn{2}{|c|}{$12.8(0.03)$} \\
\hline
\end{tabular}

0.28 to $0.30 \%$ in maize and 0.78 to $0.83 \%$ in cotton seed + lint in year 4 .

The harvest indices for $\mathrm{K}(\mathrm{KHI})$ derived for each crop at each site ( $\mathrm{K}$ removed in grain as a proportion of $\mathrm{K}$ in total biomass; Table 5) all showed a decline as $\mathrm{K}$ rate increased, indicating that greater proportions of crop $\mathrm{K}$ were redistributed to the soil surface by crop residues as soil K status improved. However, the differential between $\mathrm{K}$ treatments varied greatly between crops at a site (e.g. KHI for soybean $>$ peanut $>$ cotton $>$ maize at Taabinga) and there was greater proportional removal of $\mathrm{K}$ in 
crops at Taabinga than Wooroolin (an average KHI over all crops and treatments of 0.31 compared with 0.11 ; Table 5). This difference in relative $\mathrm{K}$ removal rates at the 2 sites was consistent with the more rapid stratification of $\mathrm{K}$ in the top $0.1 \mathrm{~m}$ of the profile in the ploughed treatment over the experimental period at Wooroolin than Taabinga (Table 4).

\section{Field study at Haly Creek-impacts of degree of mixing of applied $\mathrm{K}_{2} \mathrm{SO}_{4}$ fertiliser}

In common with the Wooroolin study (Table 3), treatments produced significant differences in soil exchangeable $\mathrm{K}$ in only the top $0.3 \mathrm{~m}$ of the soil profile (data not shown). Exchangeable $\mathrm{K}$ in the top $0.1 \mathrm{~m}$ of the profile either increased by $20 \%$ (strip till and deep rip) to $40 \%$ (surface) or decreased by $40 \%$ (ploughed) relative to the control treatment (Table 1), depending on degree of mixing. In the $0.1-0.2$ and $0.2-0.3 \mathrm{~m}$ layers, the relative increases compared to the control treatment were much greater, especially in the ploughed treatment, with exchangeable K increasing by $70 \%$ (surface and strip till), 180\% (deep rip), and $280 \%$ (ploughed) in the $0.1-0.2 \mathrm{~m}$ layer and by $80 \%$ (strip till) and $260 \%$ (ploughed) in the $0.2-0.3 \mathrm{~m}$ layers.

However, unlike the peanut crop grown in the Brown Ferrosol at Taabinga (Table 5), there were significant differences between tillage treatments in both biomass production and access to applied $\mathrm{K}$ fertiliser (measured as $\mathrm{K}$ in biomass) by the peanut crop grown on the Red Ferrosol at Haly Creek (Fig. 4). Relative to the control treatment without any $\mathrm{K}$ fertiliser, biomass increased by up to $30 \%$, but even greater increases in biomass $\mathrm{K}$ concentration (up to $50 \%$ increase) saw crop $\mathrm{K}$ uptake effectively double. The larger increases in $\mathrm{K}$ accumulation in crop biomass were consistent with the large differences in the peanut crop grown in the study on the BF1 soil at Taabinga (Table 5), but the significant increase in $\mathrm{K}$ uptake with differing amounts of tillage and fertiliser $\mathrm{K}$ redistribution was unexpected. Using the undisturbed soil with $\mathrm{K}$ broadcast onto the soil surface as a reference, increasing the amount of tillage from a narrow $(0.3-\mathrm{m})$ strip to full-tined cultivation to profile inversion resulted in small biomass increases $(2 \%, 7 \%$, and $20 \%$, respectively) but much larger

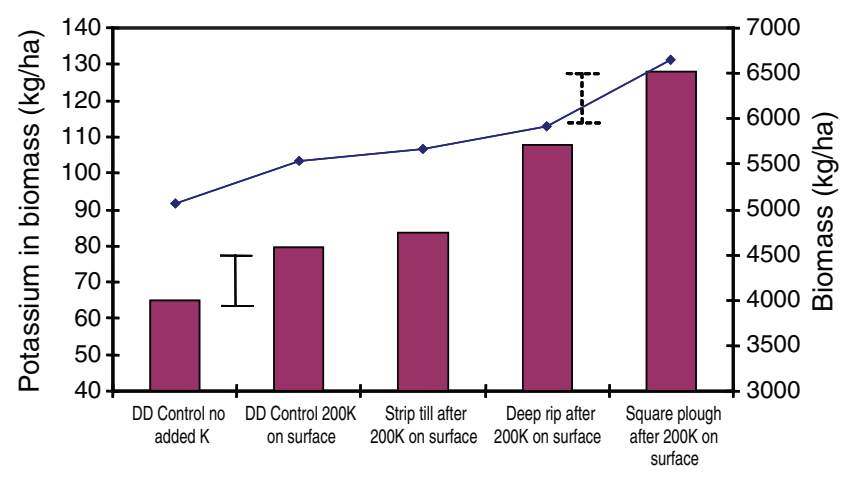

Fig. 4. Effect of $\mathrm{K}$ fertiliser application and degree of soil mixing on biomass production and $\mathrm{K}$ accumulation by the peanut crop at Haly Creek. Capped lines (solid, crop K content, $\mathrm{kg} \mathrm{K} / \mathrm{ha}$; broken, crop biomass, $\mathrm{kg} / \mathrm{ha}$ ) indicate the 1.s.d. $(P=0.05)$ for treatment comparison. increases in $\mathrm{K}$ accumulation $(5 \%, 35 \%$, and $61 \%$, respectively) due to increasing biomass $\mathrm{K}$ concentrations.

\section{Field studies involving deep banding of mixed $\mathrm{KCl}$ and DAP fertilisers-Chelmsford}

The Chelmsford series of experiments (Table 6) produced consistent biomass and $\mathrm{K}$ accumulation differences between treatments at only 2 of the sites (BD1 and BV1) in both the first and second crop cycles. While there were clear and significant increases in $\mathrm{K}$ accumulation with the treatment containing deep-banded $\mathrm{KCl}$ at both these sites, the biomass responses produced in the $(\mathrm{DAP}+\mathrm{KCl})$ treatment were not significantly different from that with deep placement of DAP alone (i.e. due to factors other than the $\mathrm{K}$ fertiliser, such as the loosening of compacted subsoils). In addition to these 2 sites with responses in both crop seasons, a biomass response to deepbanded $\mathrm{KCl}$ was recorded at RF1 and additional $\mathrm{K}$ uptake was measured at RF1 and BV2 in the first crop season only. The shallow $(\mathrm{DAP}+\mathrm{KCl})$ treatment at $\mathrm{RF} 2$ produced no significant impact on biomass or $\mathrm{K}$ uptake in either season, while the shallow incorporated rates of $\mathrm{KCl}$ at $\mathrm{BV} 1$ had no significant effect on biomass production and resulted in no more crop $\mathrm{K}$ uptake than the deep banded (DAP $+\mathrm{KCl}$ ) treatment.

Recovery of applied $\mathrm{K}$ fertiliser in crop biomass was generally low (i.e. $<15 \%$ ), with the exception of BV1 and $\mathrm{BD} 1$, although recoveries were noticeably higher in both crops grown on BV1 than BD1 for comparable $\mathrm{K}$ application rates (i.e. an average of $50-55 \%$ in crop 1 and crop 2 at BV1 $v$. $17-18 \%$ on BD1 (Table 6). Interestingly, samples of the indicator leaf taken from the BD1 site in both crop seasons (data not presented) showed that despite the increased $\mathrm{K}$ uptake by the crop growing in the (DAP $+\mathrm{KCl})$ treatment, plants were still K-deficient (Reuter and Robinson 1997).

Although fertiliser $\mathrm{K}$ recoveries were high at some sites, the residual $\mathrm{K}$ left for subsequent crop cycles was large. The greatest amount of fertiliser $\mathrm{K}$ removed in harvested product (seed or pods) was only $7 \mathrm{~kg} / \mathrm{ha}(<10 \%$ applied $\mathrm{K})$ at BV1. It was a little surprising, therefore, that despite the obvious retention of the majority of the applied $\mathrm{K}$ fertiliser in the soil and residues for the second crop cycle, additional $\mathrm{K}$ accumulation in biomass was limited to the $\mathrm{K}$ treatments at BV1 and BD1.

\section{Discussion}

Declining reserves of plant-available $\mathrm{K}$ in the clay soils supporting rainfed cropping in northern Australia represent a new challenge to the sustainability of the cereal/grain legume cropping systems that these soils support. The historically moderate-high fertility levels in these soils (Webb et al. 1997), especially in terms of $K$, has meant that there has been little work undertaken to develop predictive soil tests to indicate the need for $\mathrm{K}$ fertiliser applications until recently (Moody and Bell 2006), or to determine the most effective application strategies to ensure effective use of applied $\mathrm{K}$. The issue of emerging $\mathrm{K}$ deficiency has been complicated further by the development of increasingly heterogeneous and stratified distributions of $\mathrm{K}$ reserves in cropping soils under reduced or zero till cropping. This can occur as a result of mismatched plant row spacing and residual fertiliser bands from previous crops in 
Table 6. Biomass production and accumulation of $\mathrm{K}$ in biomass in response to fertiliser treatments in the Chelmsford sites in the year of application and the following crop season

Fertiliser $\mathrm{K}$ recovery in biomass is expressed relative to the deep DAP treatment for the (DAP $+\mathrm{KCl}$ ) treatment at each site, and relative to the farmer practice control for the surface/shallow applied treatments at RF1 and BV1. If the differential in crop K contents was negative, fertiliser recovery was assumed to be $0 \%$. Within each site/year combination, means followed by the same letter are not significantly different $(P>0.05)$ for biomass and crop K content

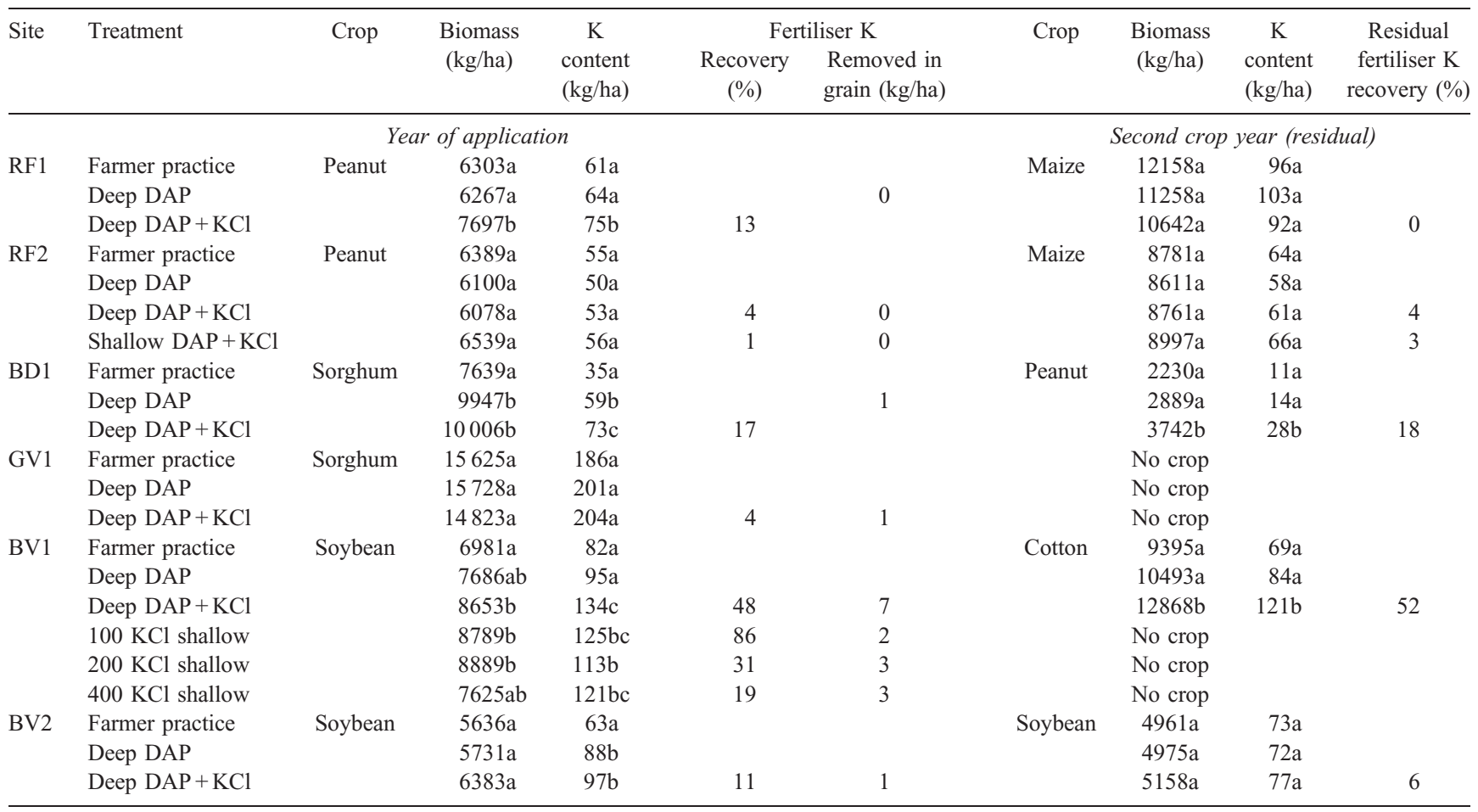

the rotation (Yin and Vyn 2003). Alternately, reserves of $\mathrm{K}$ can become increasingly concentrated in the surface soil layers (stratified) as a result of profile $\mathrm{K}$ depletion and relative surface enrichment due to residue return to the soil surface with minimal or no subsequent incorporation by tillage (Bell et al. 1995; Crozier et al. 1999). The latter situation is clearly evident in all the soil profiles where field studies were conducted (Table 1).

In order to develop effective $\mathrm{K}$ fertiliser application strategies, the size of the various $\mathrm{K}$ pools, the dynamics of their inter-relationships, and the fate of applied $\mathrm{K}$ in different soil types need to be understood. Two of the 4 soils from the incubation study (BD1 and GV2, Table 2) showed significant reserves of slow-release $\mathrm{K}$ (measured as $\mathrm{TBK}_{60}$-exchangeable $\mathrm{K}$ ), either as fixed $\mathrm{K}$ (in interlayer positions in $2: 1$ clay minerals) or as sparingly soluble K minerals (Barber 1995), and Moody and Bell (2006) showed that at least $30-60 \%$ of that slowrelease $\mathrm{K}$ was available to plants.

When fertiliser $\mathrm{K}$ was applied at varying rates to soils in the incubation study (Table 2), effectively all the $\mathrm{K}$ was recovered in the exchangeable $\mathrm{K}$ pool in all soils, even after a series of wetting and drying cycles (Fig. 1). In soils with fixed $\mathrm{K}$ reserves, the equilibrium between the exchangeable $\mathrm{K}$ and the fixed $\mathrm{K}$ pools depends on clay platelets expanding so that $\mathrm{K}$ held between the platelets can move into or out of solution and so maintain or deplete $\mathrm{K}$ on the exchange sites on exterior surfaces of the clay minerals. The rate that this can occur is dependent, among other things, on soil water content (clay platelets expand as soil moisture content increases; Mehta et al. 1992), and has clearly been shown to be reversible (Syers 1998). The virtual total recovery of applied $\mathrm{K}$ in the exchangeable $\mathrm{K}$ pool, and the consistency of this finding after a series of wetting and drying cycles, suggest that structural $\mathrm{K}$, rather than fixed $\mathrm{K}$, may be the source of the slow-release K measured in these soils. Given the lack of evidence of swell-shrink characteristics in BD1 and the floodplain alluvial derivation of GV2, this is not unexpected on the basis of other studies (Binnie and Barber 1964; Barber 1995). It also means that once these slow-release structural $\mathrm{K}$ pools have been exhausted, soil tests for exchangeable $\mathrm{K}$ will become adequate for quantification of plant-available $\mathrm{K}$ reserves.

Clay mineralogies have not been determined on soils used in these studies. However, the retention of fertiliser $\mathrm{K}$ in the exchangeable $\mathrm{K}$ pool in the upland Black Vertosol (BV1) suggests that there are unlikely to be significant quantities of vermiculite or illite clay minerals in this soil. These clay minerals are the ones primarily responsible for K fixation (Rich 1968; Malavolta 1985).

In the absence of significant fixation reactions for the added $\mathrm{K}$ fertiliser, the interactions between solution and exchangeable $\mathrm{K}$ pools will be the key determinants of $\mathrm{K}$ bioavailability. These relationships were distinctly different between the soils studied (Fig. 2a), although there were some clear groupings across soil types when solution $\mathrm{K}$ was plotted as a function of $\mathrm{K}$ saturation of the exchange complex (Fig. 2b), and to a lesser extent in terms of the slope of the relationship between $\mathrm{AR}_{\mathrm{K}}$ and the change in exchangeable $\mathrm{K}$ in response to fertiliser addition (Fig. 3). The 
rate of change in $\mathrm{AR}_{\mathrm{K}}$ with $\mathrm{K}$ fertiliser addition can be considered a surrogate measure of the $\mathrm{K}$ buffer capacity of the soil, and hence a predictor of the effectiveness of applied $\mathrm{K}$ to overcome K infertility (Evangelou et al. 1994). The slower rate of increase in soil solution $\mathrm{K}$ concentration with increasing $\mathrm{K}$ saturation for the Red Ferrosol (RF2, Fig. 3b) is consistent with the strong selectivity for $\mathrm{K}$ on the exchange complex of Red Ferrosols recorded by White (2002). This selectivity means that for a given level of K saturation (e.g. $6 \%$ of ECEC, common to all soil types after varying rates of $\mathrm{K}$ fertiliser addition in Fig. 2b), soil solution $\mathrm{K}$ concentration in the Red Ferrosol soils would be about half that in the other soil types (calculated as $46 v .95 \mathrm{mg} \mathrm{K} / \mathrm{L}$ ). However, it is unusual to see these high levels of $\mathrm{K}$ saturation in soils in the field, especially in the Vertosols. At exchangeable K concentrations typically found in soils in the field (Table 1) and at realistic rates of $\mathrm{K}$ application $(50-100 \mathrm{~kg} \mathrm{~K} / \mathrm{ha})$, both $\mathrm{K}$ saturation and the resulting solution $\mathrm{K}$ concentrations were generally higher in the Red Ferrosols despite this apparent $\mathrm{K}$ selectivity.

Because crop demand for $\mathrm{K}$ is high, it cannot be met solely by mass flow in the transpiration stream, and diffusive supply of $\mathrm{K}$ from the soil solution is an important mechanism (Barber 1985; Syers 1998). The amount of an ion transported by diffusion is the product of the effective diffusion coefficient and the concentration gradient. Assuming that plant roots rapidly deplete soil solution $\mathrm{K}$ in their immediate vicinity, the rate of diffusive replenishment will be a function of the background solution $\mathrm{K}$ concentration (as this determines the concentration gradient) and the extent to which that solution $\mathrm{K}$ is buffered by the exchangeable $\mathrm{K}$ pool (in the absence of fixed and structural $\mathrm{K}$ sources), as this affects the effective diffusion coefficient. It is reasonable to assume that soils with a very high $\mathrm{KBC}$ (Fig. 3) and a low background soil solution $\mathrm{K}$ concentration or $\mathrm{AR}_{\mathrm{K}}$ that is relatively unresponsive to applied $\mathrm{K}$ fertiliser (Fig. $2 a, b$ ) will be less efficient at supplying $\mathrm{K}$ by diffusive flow to the soil-root interface. This hypothesis is supported by the extent to which luxury $\mathrm{K}$ accumulation was observed in crop biomass in field studies at Taabinga compared to Wooroolin (Table 5). Despite much lower background exchangeable $\mathrm{K}$ at Taabinga, fertiliser $\mathrm{K}$ rates that produced a similar increase in exchangeable $\mathrm{K}$ at both sites (increases of up to $0.4-0.5 \mathrm{cmol}(+) / \mathrm{kg}$ ) produced a much greater response in $\mathrm{K}$ accumulation (Table 5) at Taabinga. The combination of strongly buffered soils with relatively weak concentration gradients may be at least part of the explanation for the very high $\mathrm{K}$ requirement to optimise growth responses reported for heavier clay soils by Collett (1997), and is a warning for broadacre grain cropping regions on such soils to not allow negative $\mathrm{K}$ balances to erode soil $\mathrm{K}$ reserves too far.

The differential availability of $\mathrm{K}$ fertiliser applied to soils with contrasting $\mathrm{KBC}$ suggests that different application strategies may be required for different soil types. Soils with a low KBC such as the Red and Brown Ferrosols and Dermosols in this study may respond best to mixing of $\mathrm{K}$ fertiliser through a reasonable soil volume, as soil solution $\mathrm{K}$ is quite responsive to small changes in exchangeable $\mathrm{K}$ and diffusive supply to the root is quite efficient. On the other hand, crops grown on strongly buffered Vertosols like BV1 may be more responsive to $\mathrm{K}$ applied in concentrated bands that allow the development of strong solution $\mathrm{K}$ concentration gradients, thus partially compensating for the low effective diffusion coefficient. The relatively efficient recovery of banded $\mathrm{K}$, either applied shallow with a scarifier or deep with the Yeomans ripper on BV1 (Table 6) in the Chelmsford study, tends to support this, as does the relatively poor recovery of $\mathrm{K}$ in the Red Ferrosols (RF1 and RF2) and the inability to obtain enough $\mathrm{K}$ to overcome $\mathrm{K}$ deficiency in the Brown Dermosol (BD1) in the same study. The BD1 results suggest that it is unlikely that a sufficiently large proportion of the crop root system would be contacted by a single band of $\mathrm{K}$ fertiliser per crop row for crop $\mathrm{K}$ demands to be met (even though banding is the most efficient method of applying K in soils of high KBC) (Kovar and Barber 1987). Multiple bands might be required to satisfy crop requirements, raising the issue of $\mathrm{K}$ fertiliser management in a crop rotation. With permanent beds and precision agriculture, it may be possible to apply a single band of $\mathrm{K}$ fertiliser during the planting of each crop, but with the position of the band off-set from bands residual from previous crops. This might be an alternative approach to $\mathrm{K}$ fertiliser management in these soils rather than distributing large amounts of $\mathrm{K}$ fertiliser through the root-zone by zonal tillage. Further field work on $\mathrm{K}$ application strategies on medium-heavy clay soils with contrasting $\mathrm{K}$ status and $\mathrm{KBC}$ is needed to resolve these issues.

Despite the strong stratification of $\mathrm{K}$ reserves in all field sites and the generally low exchangeable $\mathrm{K}$ in subsoil layers (Table 1), the evidence of a beneficial effect of mixing/ placing $\mathrm{K}$ fertilisers into those depleted subsoil layers was limited. Ploughing was able to redistribute applied $\mathrm{K}$ into the $0.2-0.3 \mathrm{~m}$ layer at Taabinga (BF1, Table 3 ) and Haly Creek (RF3, data not shown), although the mixing into the $0.2-0.3 \mathrm{~m}$ layer at Wooroolin was less effective (BV3, Table 3), and the deep bands in the Chelmsford study were consistently placed at $0.25-0.3 \mathrm{~m}$. However, while the peanut crop at Haly Creek showed increased access to fertiliser with increasing enrichment of deeper soil layers by more vigorous tillage (Fig. 4), there was no difference between shallow discs, deep bands, or ploughing in the Taabinga and Wooroolin studies (Table 5), and recovery of $\mathrm{K}$ from deep bands at Chelmsford (Table 6) was generally quite poor, with the exception of the Black Vertosol (BV1) discussed earlier.

The apparently conflicting effect of overcoming surface stratification at BF1 (Taabinga) and BV3 (Wooroolin), where no benefits of mixing were recorded, and RF3 (Haly Creekgreater $\mathrm{K}$ uptake as mixing increased) can be explained when considering the mixing methods employed at the different sites. The control treatments on BF1 and BV3 were tilled with offset discs, which effectively mixed applied $\mathrm{K}$ through the top $0.1-0.15 \mathrm{~m}$ of the soil profile in sites which had previously been conventionally tilled (Table 3 ). However, the RF3 site had been direct-drilled in recent seasons, and the control treatment (with or without $\mathrm{K}$ ) was also direct-drilled, so there was effectively no mixing at all. The intermediate mixing treatments (strip tillage and ripping) were both only conducted with tined implements (and only in a narrow band along the planting row in the case of strip tillage), so redistribution of broadcast $\mathrm{K}$ into deeper soil layers would have been limited. In effect, there were no treatments that would have approximated the degree of surface incorporation of the offset discs at the other 2 sites, so it is not surprising that 
access to $\mathrm{K}$ increased as soil disturbance increased (Fig. 4), especially given the inability of $\mathrm{K}$ to leach in these soil types (White 2002).

The Haly Creek results are a clear example of the problems that will be encountered with an increasing incidence of $\mathrm{K}$ deficiency in direct-drill systems on clay soils where $\mathrm{K}$ leaching is minimal and crops rely on subsoil moisture for prolonged periods during the growing season (Freebairn et al. 1997). Current fertiliser application strategies typically consist of pre-plant $\mathrm{N}$ application (banded urea or anhydrous ammonia), followed by low rates of starter fertiliser (blended $\mathrm{N}$ and $\mathrm{P}$, often with $\mathrm{Zn}$ ) in the seeding row at planting. Growers are already constrained by the fertiliser rates that can be applied in the seeding furrow due to negative impacts on crop establishment, especially in summer crops such as sorghum that are grown in row spacings $\geq 1.0 \mathrm{~m}$. Surface broadcasting of $\mathrm{K}$ is used in direct-drill systems in North America, where less frequent moisture deficits represent a less likely constraint to root access, but even in those conditions, problems with $\mathrm{K}$ availability are encountered (Yin and Vyn 2003), and the situation is likely to be exacerbated under the much drier Australian conditions. It is therefore likely that pre-plant applications will be necessary, meaning another field operation (where anhydrous ammonia is used to supply $\mathrm{N}$ ) and an improved understanding of the most effective application rates, band spacing, and form of applied $\mathrm{K}$ to optimise crop recovery. There are considerable uncertainties about all of these issues currently.

Finally, maize (Welch and Flannery 1985), soybean (Hanway and Johnson 1985) and peanut (White 2002) all exhibit more rapid $\mathrm{K}$ accumulation than that of biomass in relative terms, and all crops grown in these studies showed the ability to accumulate $\mathrm{K}$ in crop biomass in excess of that required to optimise biomass production (i.e. luxury accumulation, Table 5). While the $\mathrm{K}$ concentration in biomass increased with increasing $\mathrm{K}$ availability, that of grains/pods/seed + lint increased only marginally, if at all. The resulting large differences in the proportion of biomass $\mathrm{K}$ removed in the harvested produce (KHI) were strongly influenced by $\mathrm{K}$ status and crop species (Table 5), and the combination of these influences explains the more rapid decline in soil $\mathrm{K}$ status at Taabinga and the redevelopment of stratified $\mathrm{K}$ profiles in ploughed treatments at both sites (Table 4). The apparently greater re-stratification of K in $\mathrm{BV} 3$ at Wooroolin is a result of proportionally lower $\mathrm{K}$ removal than in BF1 at Taabinga, with the residual K returned to the surface soil in residues.

\section{Conclusions}

Continuing negative $\mathrm{K}$ balances will ensure the need to address $\mathrm{K}$ fertility management strategies in clay soils supporting broadacre cropping systems. Seasonal moisture limitations and the relative immobility of $\mathrm{K}$ in the soil mean that some incorporation of $\mathrm{K}$ fertilisers into the profile will be required, although our data do not support the need for thorough profile mixing (ploughing) or subsoil applications. However, practical issues associated with limitations to the amount of fertiliser that can be applied with the seed at planting suggest that growers will have to modify current fertiliser strategies when $\mathrm{K}$ applications become warranted. This will be particularly relevant to growers who have adopted direct drill systems with minimal soil disturbance, and further work to define appropriate $\mathrm{K}$ fertiliser application strategies in these systems is needed.

Our data have provided clear evidence of the impact of soil properties (i.e. $\mathrm{KBC}$ ) on the dynamics of applied $\mathrm{K}$ fertilisers in soil and the resulting accumulation of $K$ by crops. Results suggest that fertiliser application strategies may need to vary between soils with high and low $\mathrm{KBC}$, and further research is needed to clarify this.

\section{Acknowledgments}

The authors would like to acknowledge the support of the Grains Research and Development Corporation through funding to DAQ00471, DAQ00063 and DAQ00084, and recognise the support from the many growers in the inland Burnett who allowed access to their farm to conduct long-term field trials. In particular, the support from the Bauer, Jones, Labuschewski, and Kearney families and the Chelmsford grower group is much appreciated.

\section{References}

Australian Agriculture Assessment (2001) Nutrient management in Australian agriculture. In 'Australian agriculture assessment. Vol. 1'. (National Land and Water Audit: Canberra, ACT)

Barber SA (1985) Potassium availability at the soil-root interface and factors influencing potassium uptake. In 'Potassium in agriculture'. (Ed. RD Munson) pp. 309-326. (ASA, CSSA, SSSA: Madison, WI)

Barber SA (1995) 'Soil nutrient bioavailability—a mechanistic approach.' (John Wiley and Sons Inc.: New York)

Barrow NJ (1967) Some aspects of the effects of grazing on the nutrition of pastures. Journal of the Australian Institute of Agricultural Science 33, 254-262.

Bedrossian S, Singh B (2004) Potassium adsorption characteristics and potassium forms in some New South Wales soils in relation to early senescence in cotton. Australian Journal of Soil Research 42, 747-753. doi: 10.1071/SR03143

Bell MJ, Harch GR, Bridge BJ (1995) Effects of continuous cultivation on ferrosols in subtropical southeast Queensland. I. Site characterization, crop yields and soil chemical status. Australian Journal of Agricultural Research 46, 237-253. doi: 10.1071/AR9950237

Bell MJ, Moody PW (2001) Nitrogen, potassium, calcium and magnesium balances for dryland cropping systems (Burnett region, Queensland). In 'Australian agriculture assessment. Vol. 1'. (National Land and Water Audit: Canberra, ACT)

Bell MJ, Moody PW, Harch GR, Want PW, Compton B (2005) Developing potassium fertiliser application strategies to address declining reserves in clay soils under rainfed cropping. In 'Proceedings PotOz '05: Second Workshop on Potassium in Australian Agriculture'. Melbourne.

Binnie RR, Barber SA (1964) Contrasting release characteristics of potassium in alluvial and associated upland soils in Indiana. Soil Science Society of America Proceedings 28, 387-409.

Carey PL, Metherell AK, Huen CG, Almond C (2000) Using an improved tetra-phenyl boron $\mathrm{K}$ method to measure westland soil $\mathrm{K}$ reserves. In 'Soil research: A knowledge industry for land-based exporters'. Occasional Report No. 13. (Eds LD Currie, P Longanathan) pp. 247-257. (Fertilizer and Lime Research Centre, Massey University: Palmerston North, New Zealand)

Collett IJ (1997) Potassium surveys and extension in irrigated lucerne hay. In 'Proceedings of the First Workshop on Potassium in Australian Agriculture'. Geraldton, W. Aust. (Eds MTF Wong, Y Pal, NK Edwards) pp. 47-55. (UWA Press: W. Aust.) 
Crozier CR, Naderman GC, Tucker MR, Sugg RE (1999) Nutrient and $\mathrm{pH}$ stratification with conventional and no-till management. Communications in Soil Science and Plant Analysis 30, 65-74. doi: $10.1080 / 00103629909370184$

Edwards NK (1998) Potassium. In 'Soilguide: a handbook for understanding and managing agricultural soils bulletin 4343'. (Ed. G Moore) pp. 176-180. (Agriculture Western Australia: Perth, W. Aust.)

Evangelou VP, Wang J, Phillips RE (1994) New developments and perspectives on soil potassium quantity/intensity relationships. Advances in Agronomy 52, 173-227. doi: 10.1016/S0065-2113(08) 60624-0

Freebairn DM, Connolly RD, Dimes J, Wylie PB (1997) Crop sequencing. In 'Sustainable crop production in the sub-tropics - an Australian perspective'. (Eds AL Clarke, PB Wylie) pp. 289-305. (Queensland Department of Primary Industries: Toowoomba, Qld)

Gray JM, Murphy BW (1999) Parent material and soils - A guide to the influence of parent material on soil distribution in Eastern Australia. Technical Report No. 45 (Reprinted 2002), NSW Department of Land and Water Conservation, Sydney. pp. 33-73.

Hanway JJ, Johnson JW (1985) Potassium nutrition of soybeans. In 'Potassium in agriculture'. (Ed. RD Munson) pp. 753-764. (ASA, CSSA, SSSA: Madison, WI)

Isbell RF (1996) 'The Australian Soil Classification.' (CSIRO Publishing: Collingwood, Vic.)

Kovar JL, Barber SA (1987) Placing phosphorus and potassium for greatest recovery. Journal of Fertilizer Issues 4, 1-6.

Malavolta E (1985) Potassium status of tropical and subtropical region soils. In 'Potassium in agriculture'. (Ed. RD Munson) pp. 164-194. (ASA, CSSA, SSSA: Madison, WI)

McKenzie N, Isbell R, Jacquier D, Brown K (2004) 'Australian soils and landscapes: an illustrated compendium.' pp. 362-387. (CSIRO Publishing: Collingwood, Vic.)

Mehta SC, Singh N, Singh M (1992) Effect of wetting and drying on the dynamics of potassium in some soils of Haryana. Journal of Potassium Research 8, 290-294.

Menzies NW, Bell LC (1988) Evaluation of the influence of sample preparation and extraction technique on soil solution composition. Australian Journal of Soil Research 26, 451-464. doi: 10.1071/ SR9880451

Moody PW, Bell MJ (2006) Availability of soil potassium and diagnostic soil tests. Australian Journal of Soil Research 44, 265-275. doi: $10.1071 /$ SR05154

Pretty KM, Stangel PJ (1985) Current and future use of world potassium. In 'Potassium in agriculture'. (Ed. RD Munson) pp. 753-764. (ASA, CSSA, SSSA: Madison, WI)

Rayment GE, Higginson FR (1992) 'Australian laboratory handbook of soil and water chemical analyses.' (Inkata Press: Sydney)
Reuter D, Duncombe-Wall D, Judson G (1997) Potassium balance in Australia's broadacre industries: a contemporary national and regional analysis. In 'Proceedings of the First Workshop on Potassium in Australian Agriculture'. Geraldton, W. Aust. (Eds MTF Wong, Y Pal, NK Edwards) pp. 1-8. (UWA Press: W. Aust.)

Reuter DJ, Robinson JB (1997) 'Plant analysis: An interpretation manual.' (CSIRO Publishing: Collingwood, Vic.)

Rich CI (1968) Mineralogy of soil potassium. In 'The role of potassium in agriculture'. (Eds VJ Kilmer, SE Younts, NC Brady) pp. 79-108. (American Society of Agronomy: Madison, WI)

Syers JK (1998) 'Soil and plant potassium in agriculture.' (The Fertiliser Society: Newcastle upon Tyne, UK)

Wang X, Lester DW, Guppy CN, Lockwood PV, Tand C (2007) Changes in phosphorus fractions at various soil depths following long term $\mathrm{P}$ fertiliser application on a Black Vertosol from south-eastern Queensland. Australian Journal of Soil Research 45, 524-532. doi: 10.1071/SR07069

Webb AA, Grundy MJ, Powell B, Littleboy M (1997) The Australian subtropical cereal belt: soils, climate and agriculture. In 'Sustainable crop production in the sub-tropics-an Australian perspective'. (Eds AL Clarke, PB Wylie) pp. 8-23. (Queensland Department of Primary Industries: Toowoomba, Qld)

Welch LF, Flannery RL (1985) Potassium nutrition of corn. In 'Potassium in Agriculture'. (Ed. RD Munson) pp. 753-764. (ASA, CSSA, SSSA: Madison, WI)

White J (2002) Potassium distribution in ferrosols and its influence on rain-fed crop production in the South Burnett region of Queensland. $\mathrm{PhD}$ Thesis, University of Queensland, Australia.

Wong MTF, Corner RJ, Cook SE (2001) A decision support system for mapping the site-specific potassium requirement of wheat in the field. Australian Journal of Experimental Agriculture 41, 655-661. doi: 10.1071/EA00191

Wood AW, Schroeder BL (2004) Potassium: A critical role in sugarcane production, particularly in drought conditions. In 'Proceedings, Australian Society of Sugarcane Technologists'. No. 26. (CD-ROM)

Wright P (1999) Premature senescence of cotton: Predominantly a potassium disorder caused by an imbalance of source and sink. Plant and Soil 211, 231-239. doi: 10.1023/A:1004652728420

Yin X, Vyn TJ (2003) Previous corn row effects on potassium nutrition and yield of subsequent no-till soybeans. Journal of Plant Nutrition 26, 1383-1402. doi: 10.1081/PLN-120021049

Manuscript received 21 April 2008, accepted 10 November 2008 